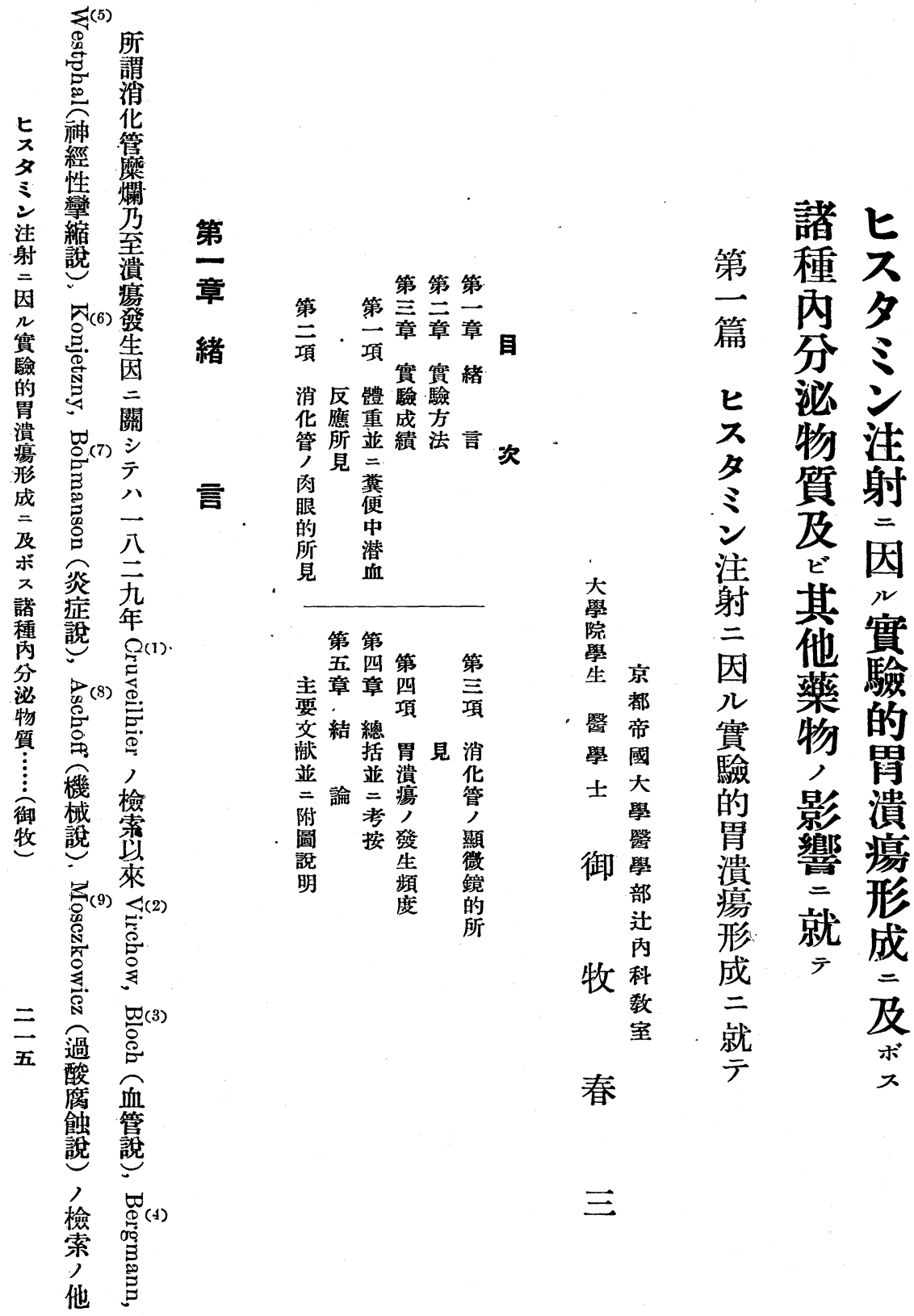


考 斯 家 注

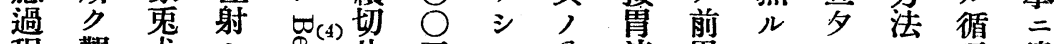
程 觀 犬

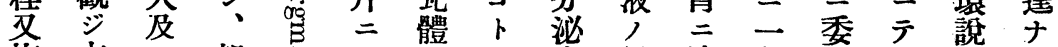

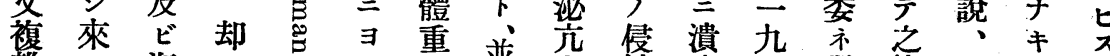

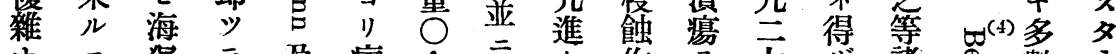

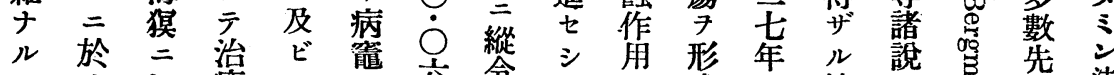

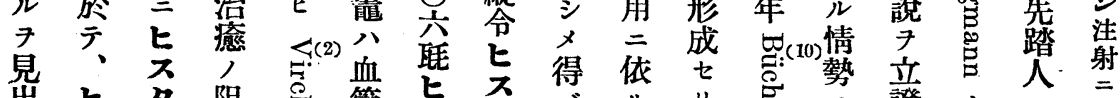
出七 多 阻 导 管 七

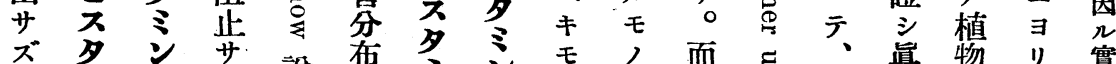

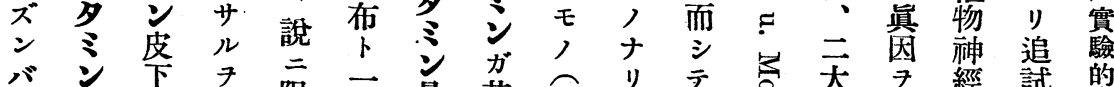
バン 下 度

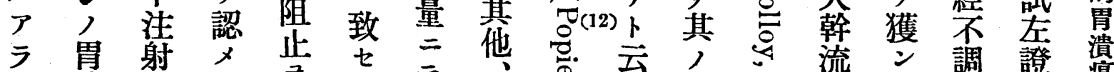
ラ、䔬 射メ步

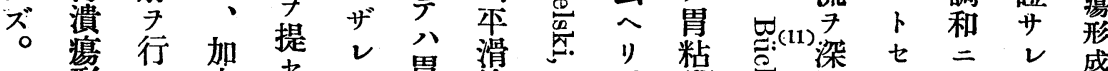

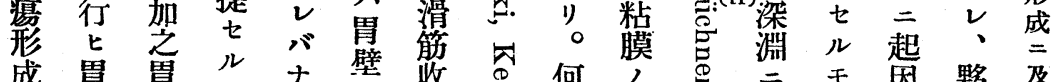

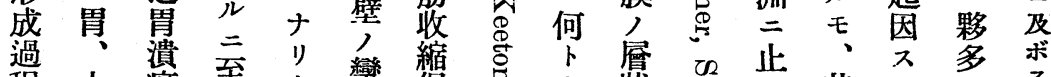

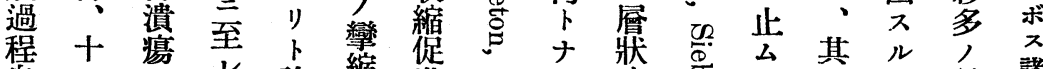

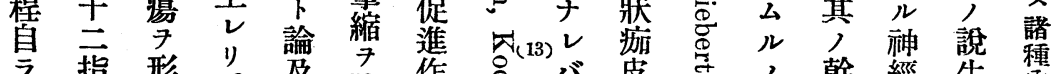

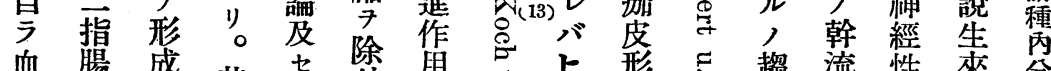

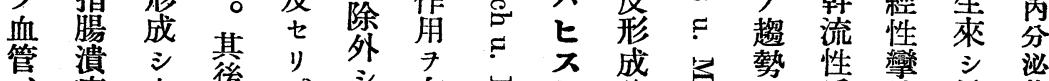

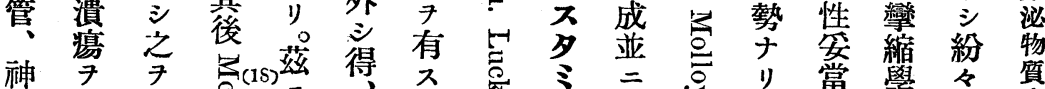

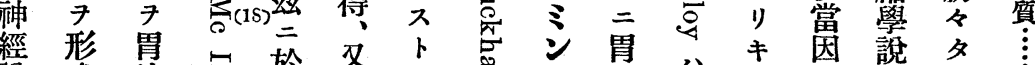

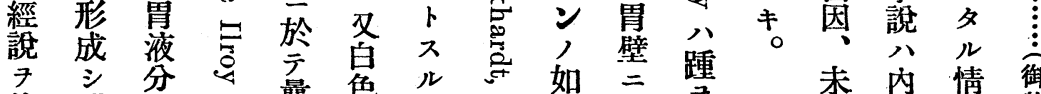

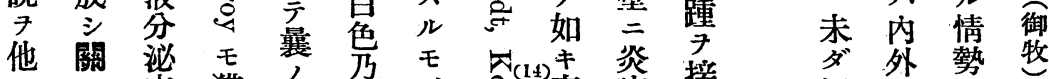

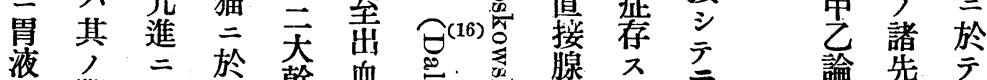

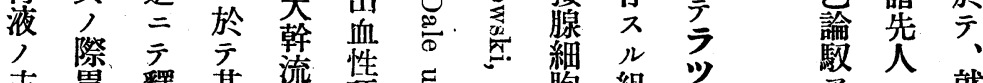

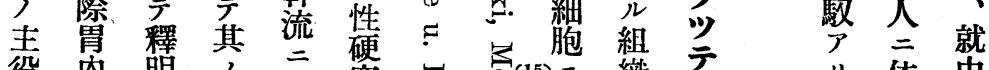
役内 明 䖝對 塞吉

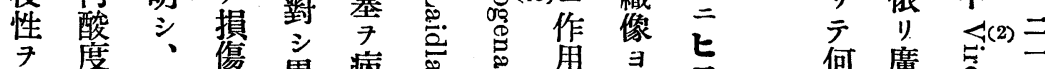

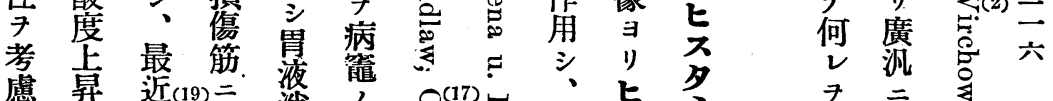

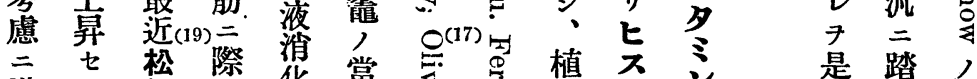

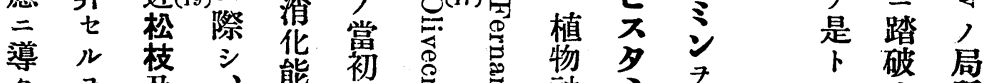

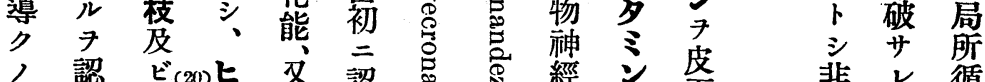

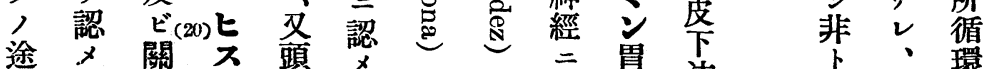

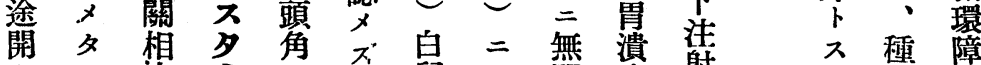
ケ、。次 


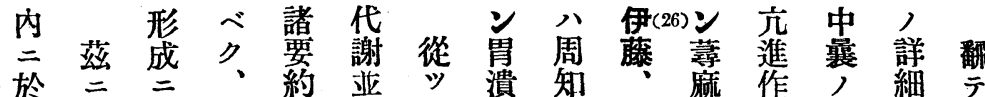

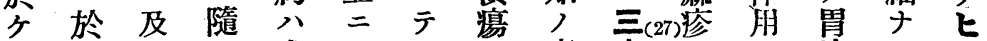
七 $テ$ デ ス 變 恩 テ 分般

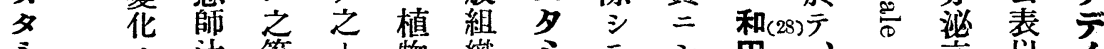

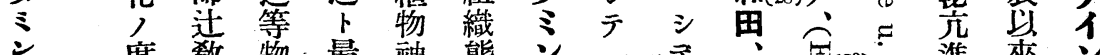

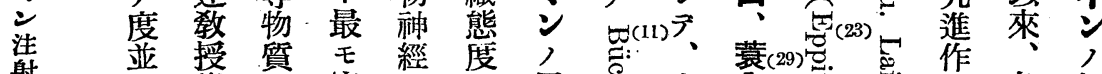

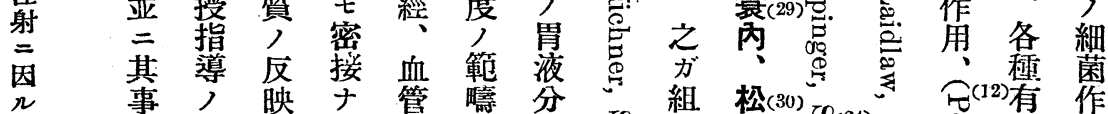

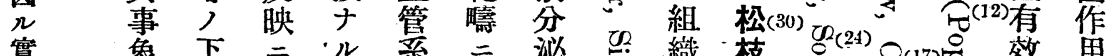

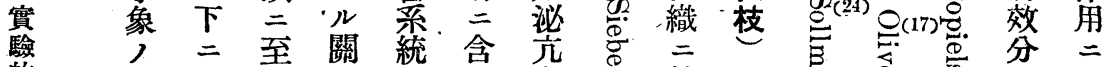

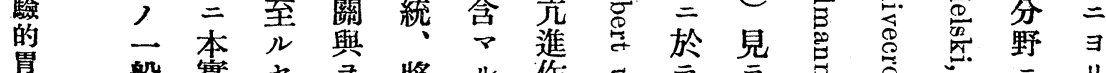

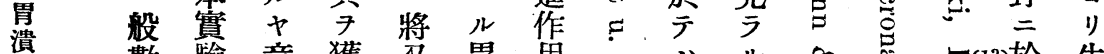

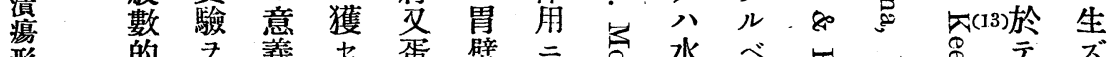
形的 7 義七蛋壁二远水 だす

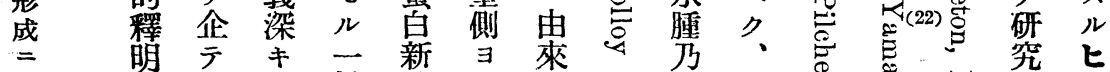

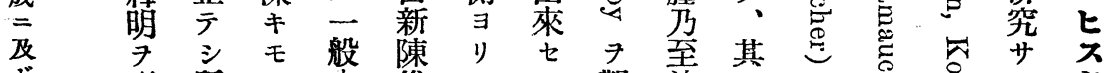

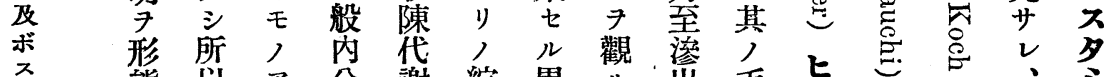

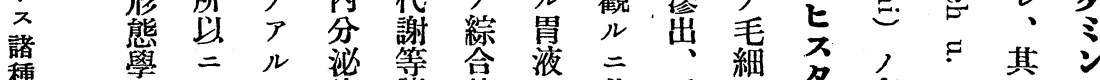
種學

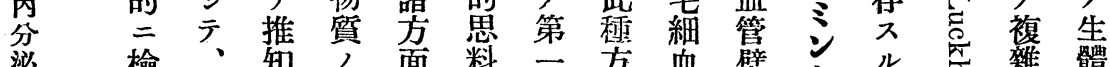

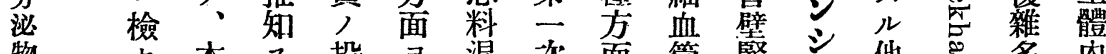
物 七 本

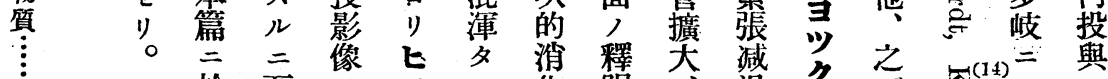

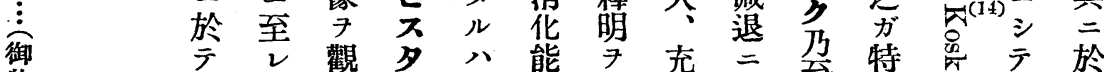
牧 少 2 觀 タ

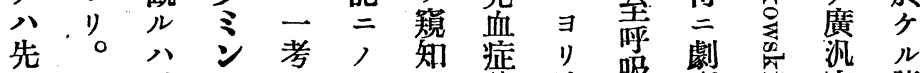

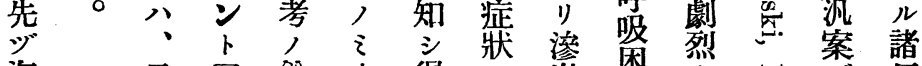

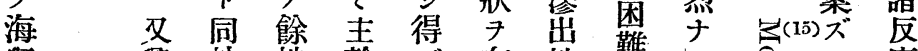

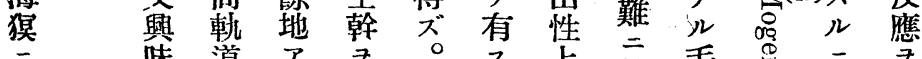

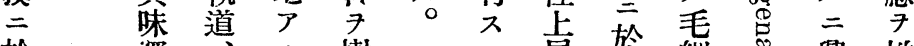

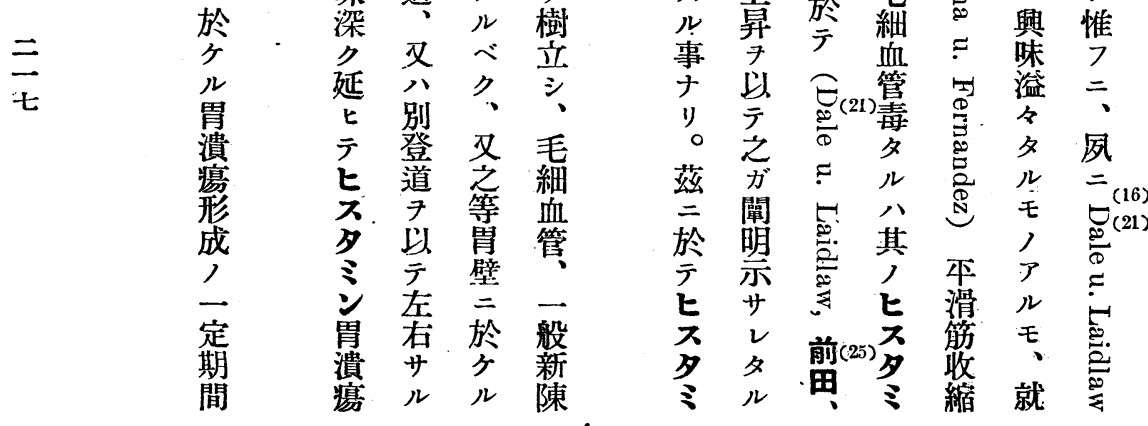




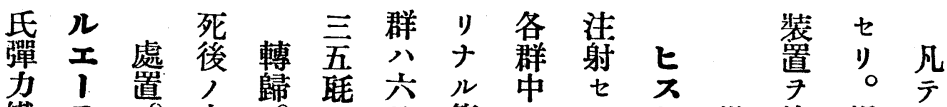

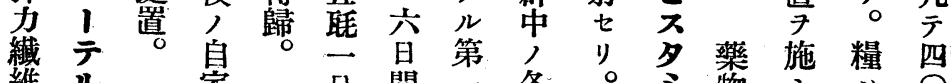

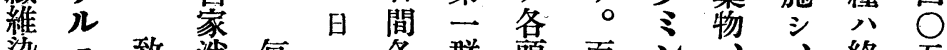

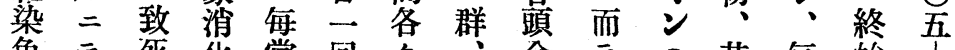
急硬死化常回々全市其每始!

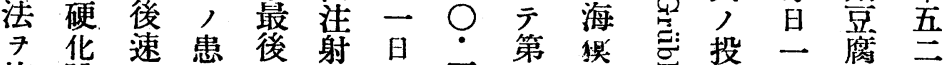

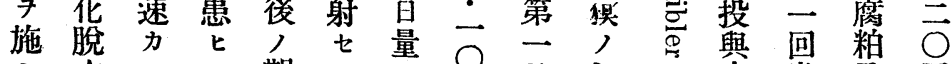
水二示期

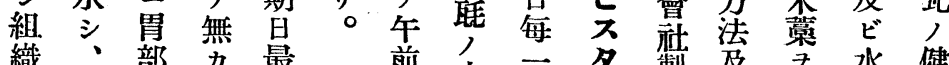
織、部分最前六二多製及年水 學チノラ終午宍 的工他 三 注 後頭 ○ン, 群換, 海 二口消 $x$ 射 豆再 檢 壬华タ後回り體對常 索 デ管り光至重入新 七严。十分第 ○鮮 》包肉四第感隇

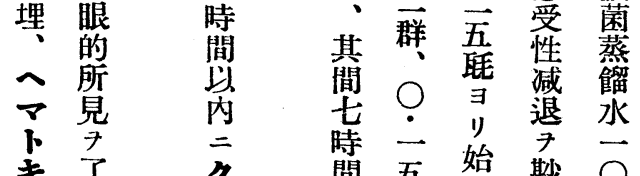

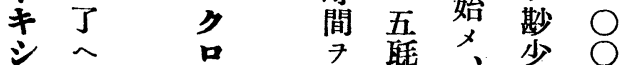

り、品隔第多O

直 7 亲第

于 方連頭 白 シ 溶

エ

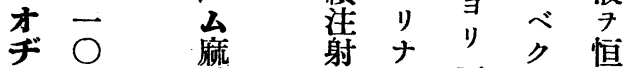

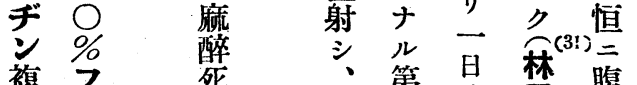

複 ᄀ死・第爷榃腹

染牙第公差思側

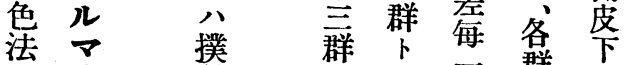

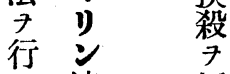

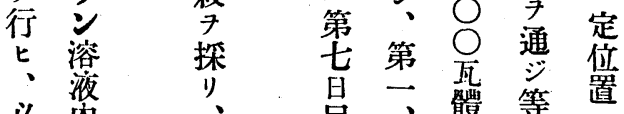

要阁期

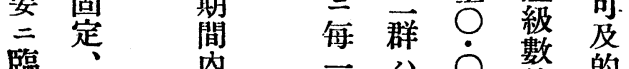

䗎次

齐恣䀢

イ

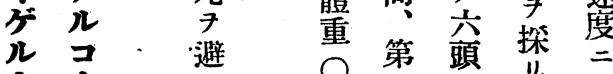

1 1 ケ

且

定週方緮

䔬量餘筬

便 7 飼

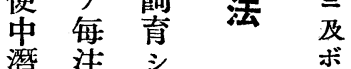

潛 注

反夏體

應 中 重

7 間 略

鈗定冬

視 時 定

ス $\rightarrow$ t

こ 日 ル

备回 後

第 乼

三 射

實實

驗

驗 的

頭 宛 雌

别給 雄

居 七 體

音。重

x 時 及

多尚近白

○第頭 捛

月

樷 對

寒 卜

夕 密

× 驗

保 $=$

温 供 
第一表 實 驗 成 績

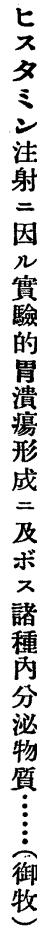

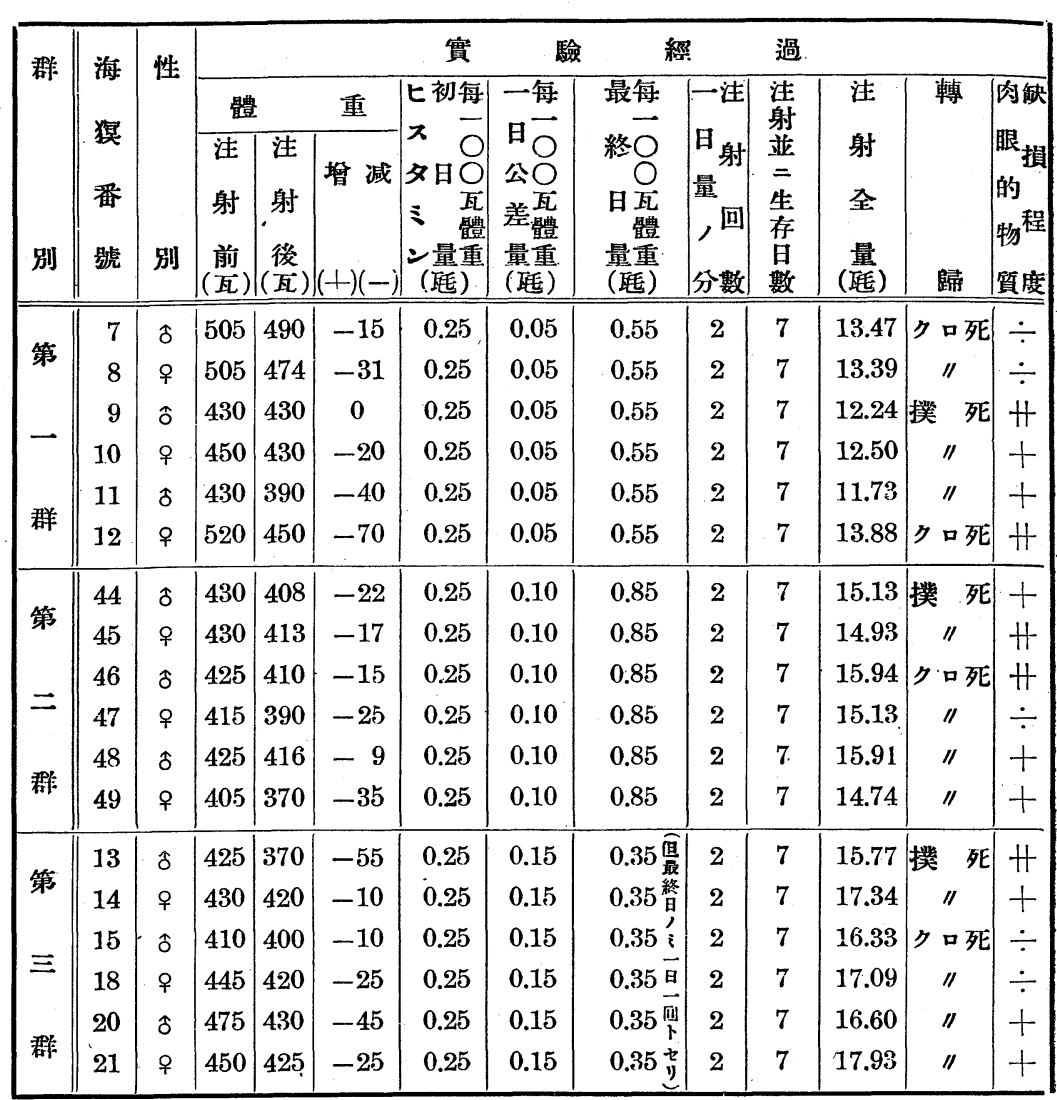

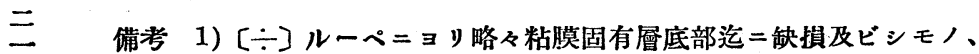

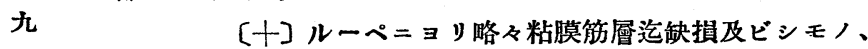

[H]ルーペニョリ略々粘膜下層汽缺損及ビシモ/ヨ指示ス。

2) クロ死ハクロロフオルム称醉死，撲死八挜殺死 7 意味ス。 


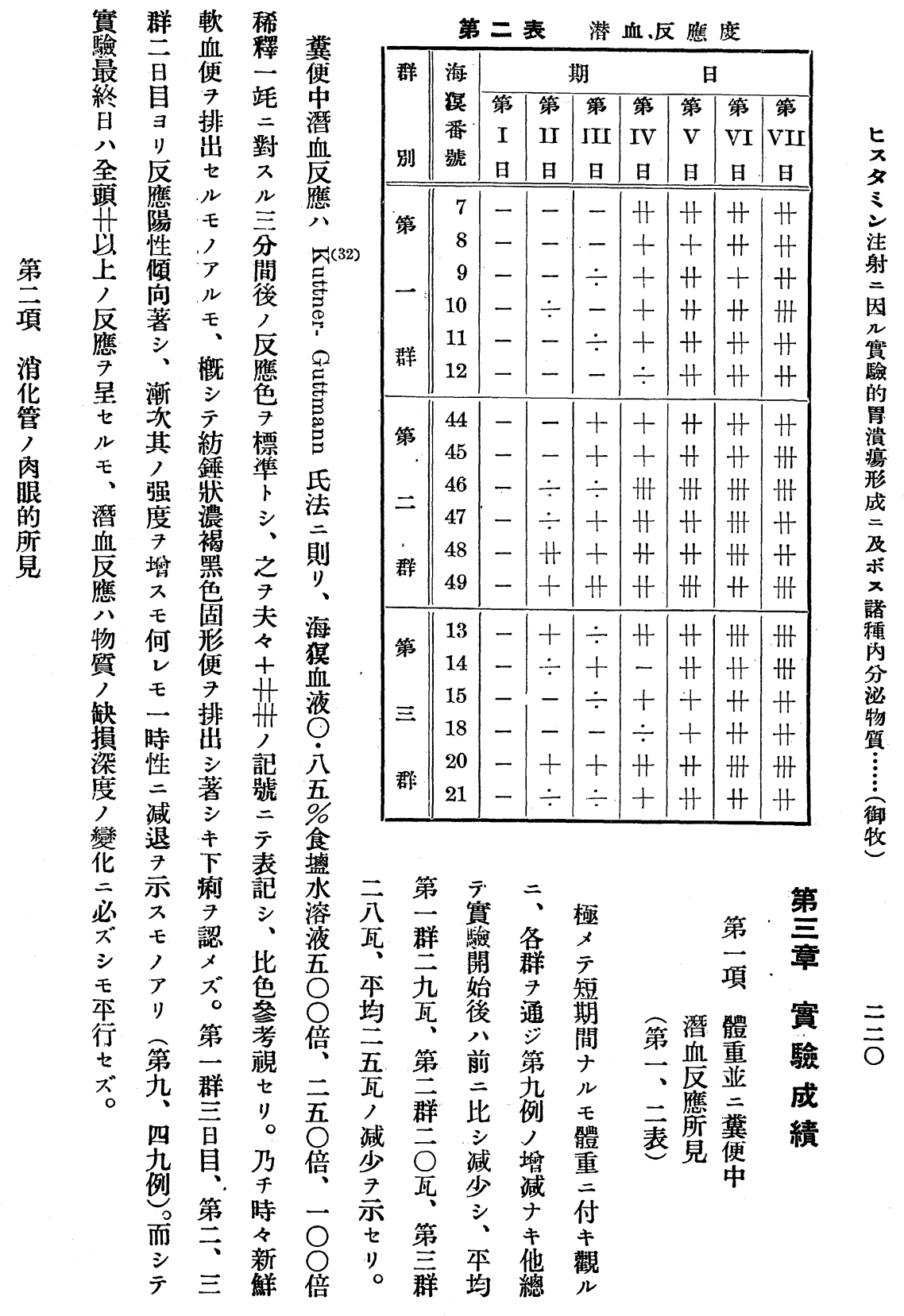




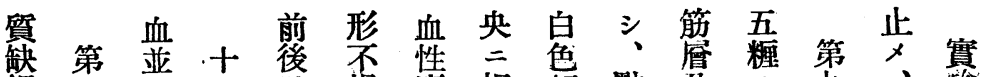

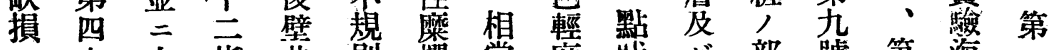

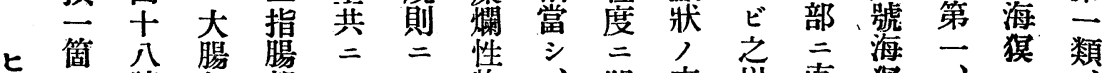

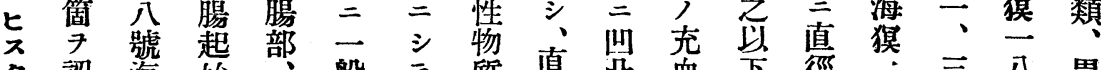

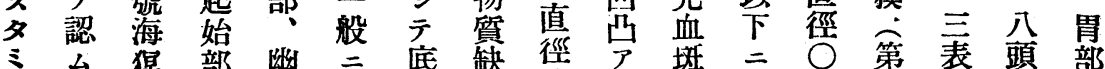

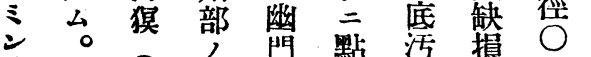

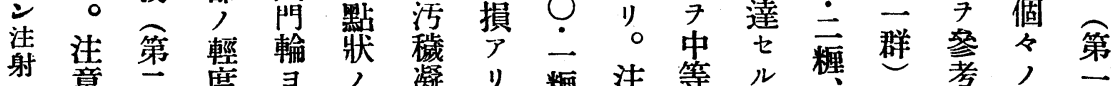

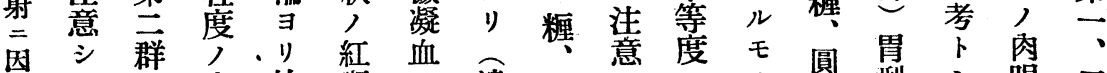

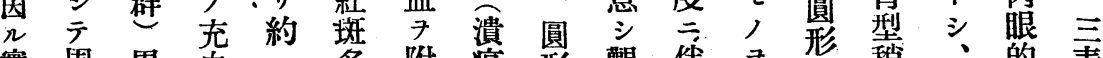
實周胃血一多附㾞形觀件

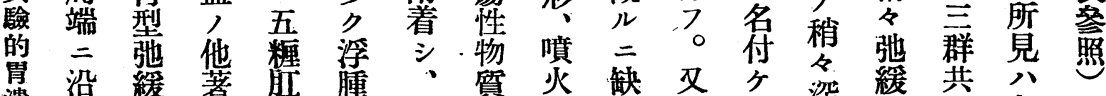

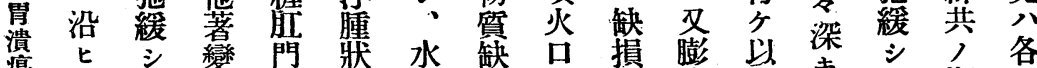

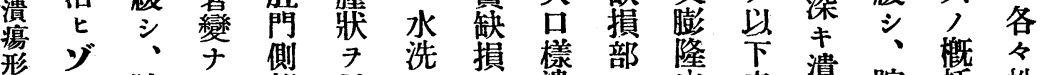

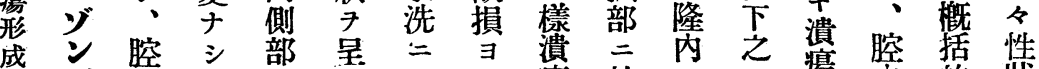

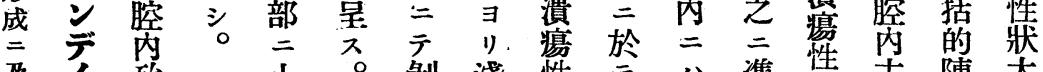
及1殆 小。剥淺性亏雀性古陳大 ボレ豆豆另物各放ズ鹠キ述同

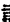

種 血

丙・ 2 t

分 バ シ

泌 輕

物 前强

質辟光

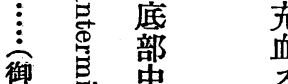

E: 央 变 粘

ス 徑

ス

底

三部 糎

凹 圆

二形趣

シ

厂噴部

污 火

穢品泆

凝 榜

血 潰

附 性

着 物

大

濾

胞

强

充

血

粘

其

充
難 略 貿 方 射 。

缺缺筷子異

今 缺向線 缺罆血ナ異

粘 損二狀 損

周膜一稍二ト 邊筒筒走周

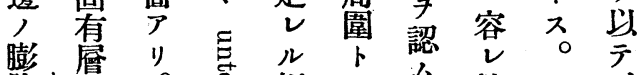

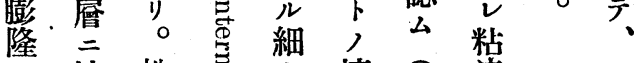

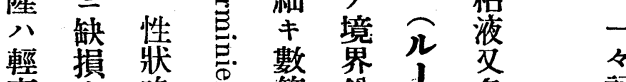

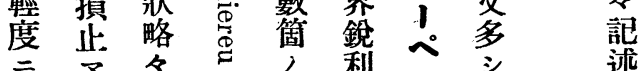
江右七溝梨三方远 テモ三ル尹シ寻後州

缺, 同モ見テ洼壁了

損 7 米, 出周堷尔煩

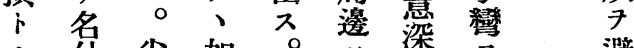
, 奀向如。这梁寻. 避

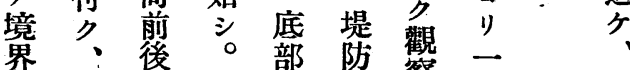
及以壁基竞狀繁 㫘之數 後略圓缺糎 瞭三简壁清味損底代 子準人幽浄子ノ底表

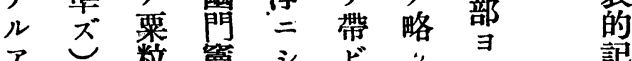

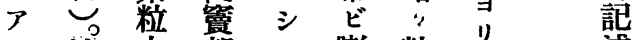

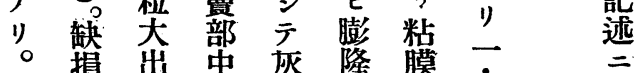




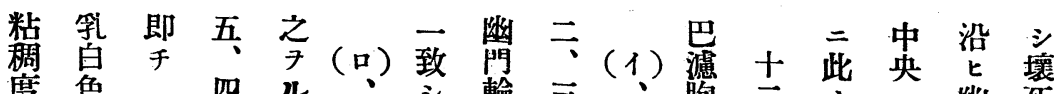

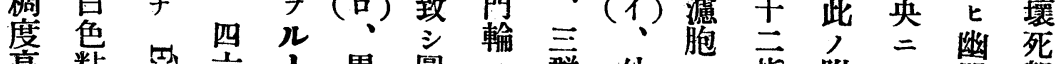

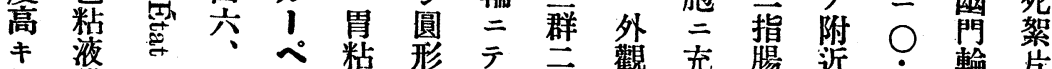

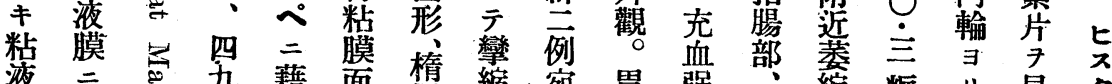

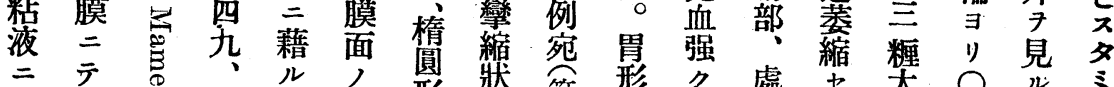

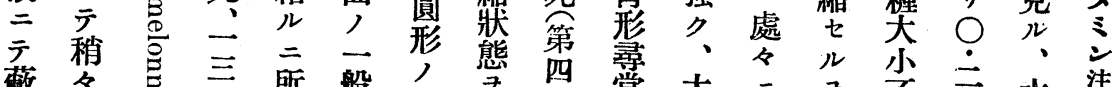

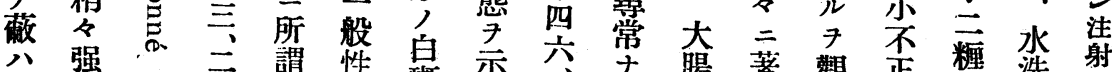

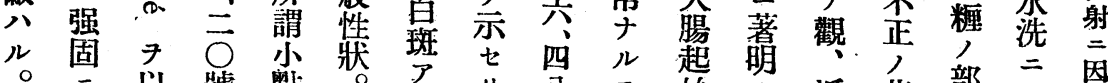

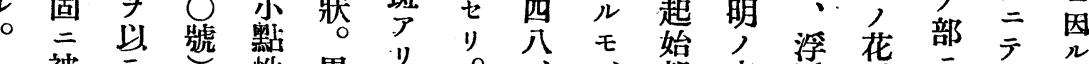

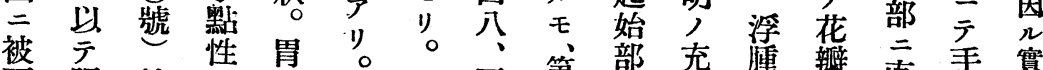
被 胒 頪

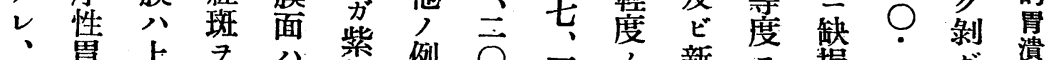

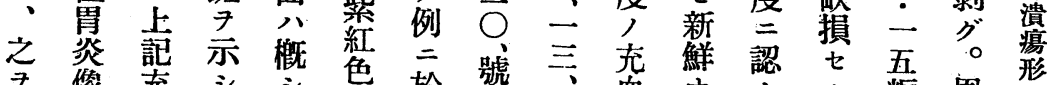

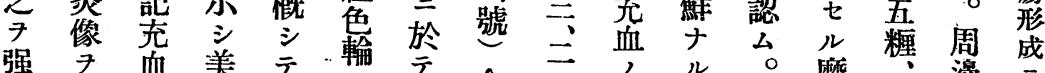

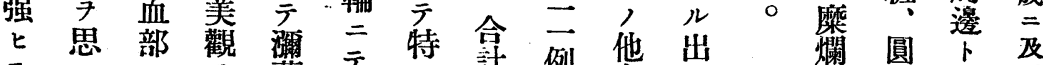

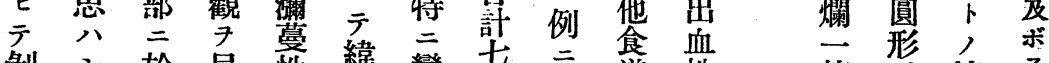

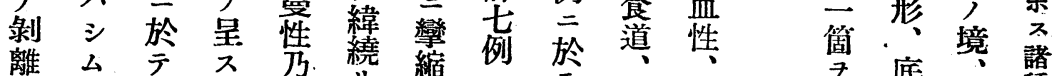

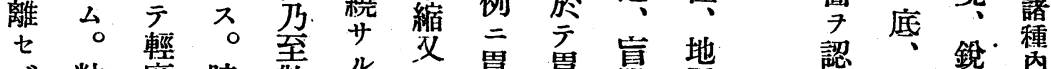

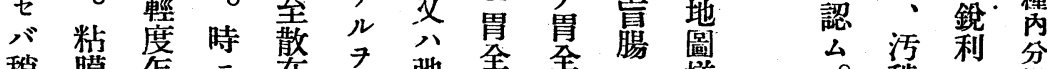

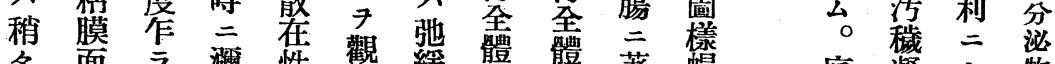

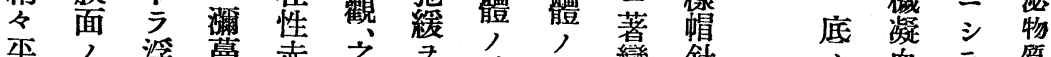

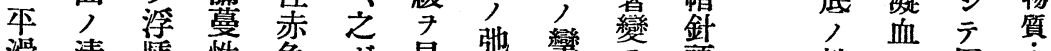

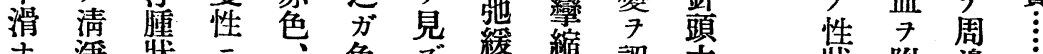

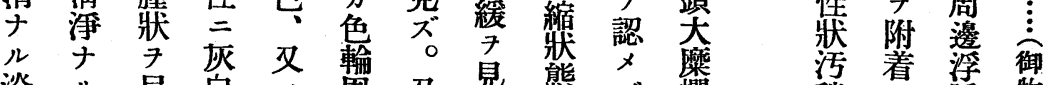

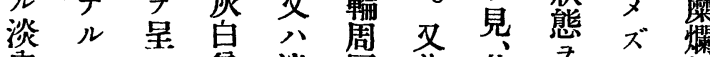

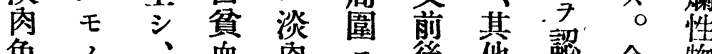

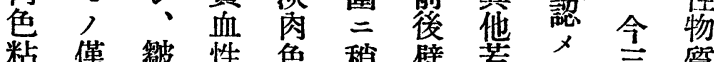

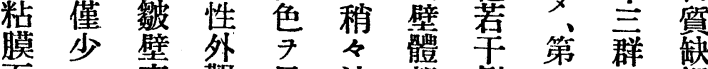
面二高觀呈波部例一共損

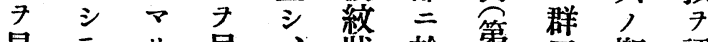
見亏. 呈: 獎 於第臂概認 出時

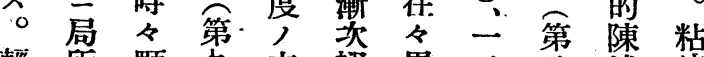
䡬 所顆九充裉胃二八述液

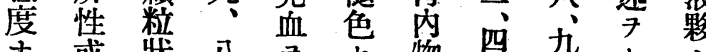

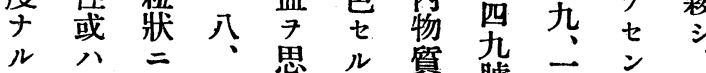

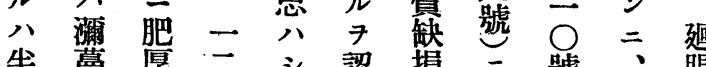

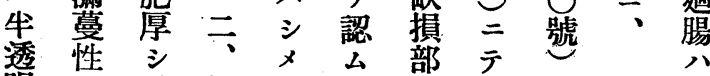
明 $=$ 、四 、台部少第淋

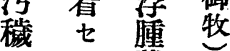

$=$ 牀

三 糜 7

礻爛 呈 周 性 邊 物 默 筫 牀

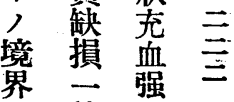
腤䈍 力認 コ 亏 天 後 少 、壁 小 淋般酔 


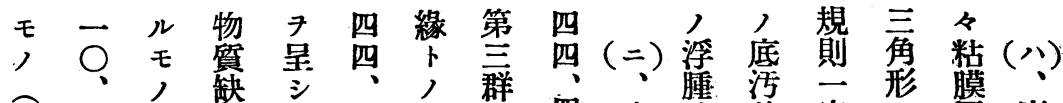

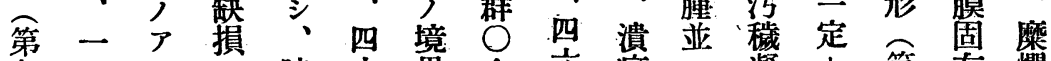

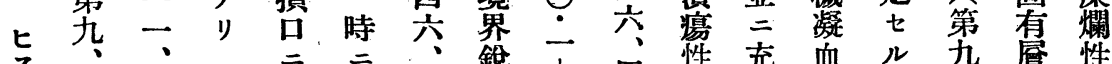

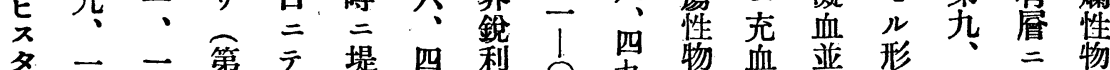
ミ三三第 示 堤 四利 洼一四一

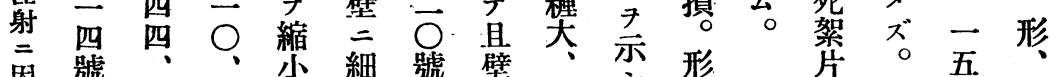

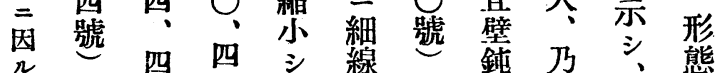

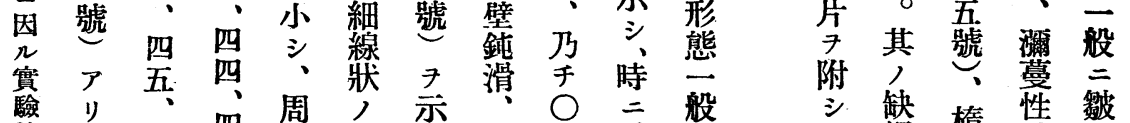

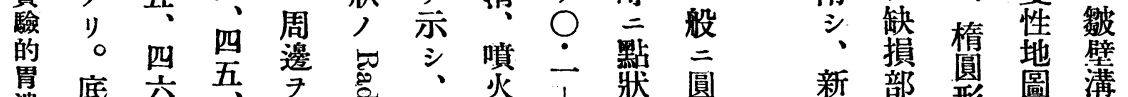
潰底 宍

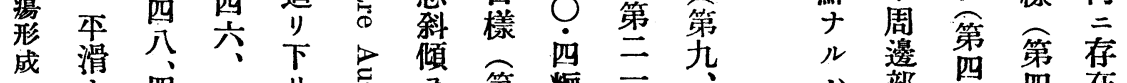

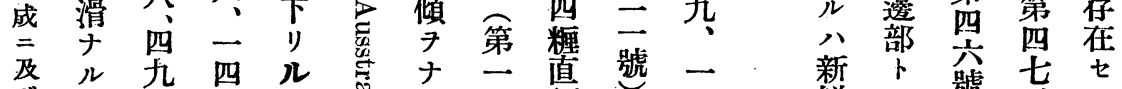

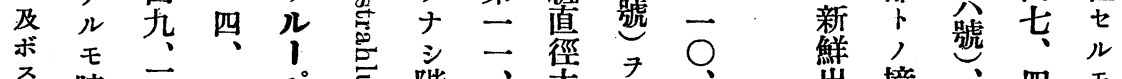

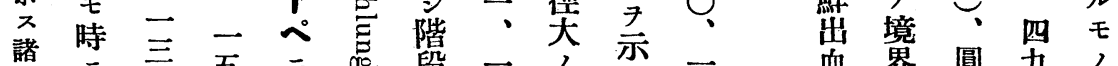

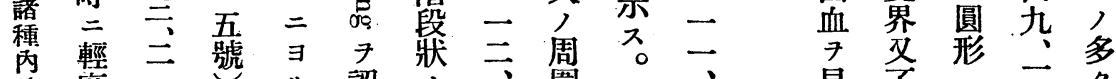

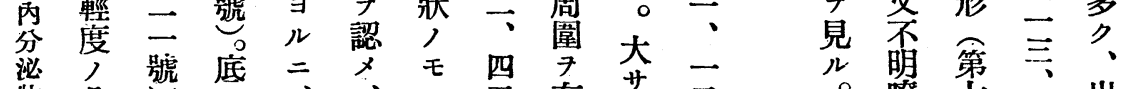

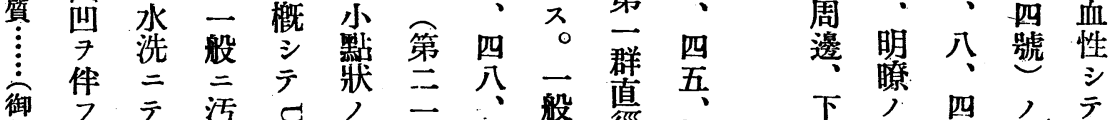
牧

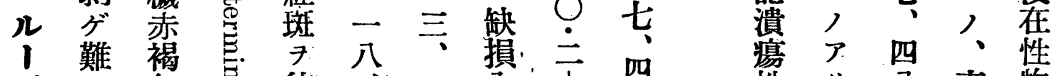

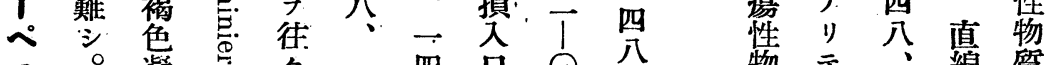

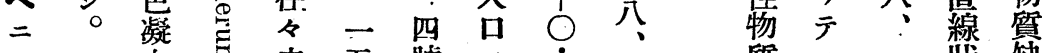

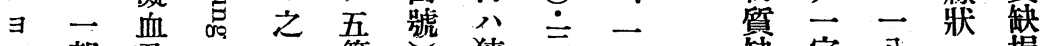
三 二 部 及

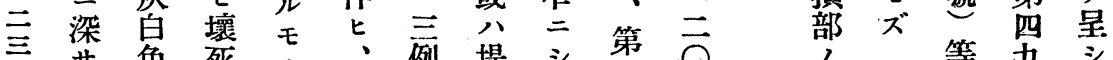

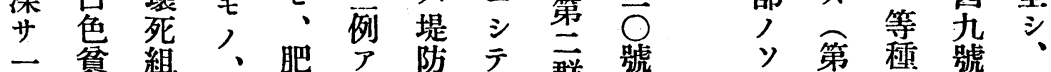

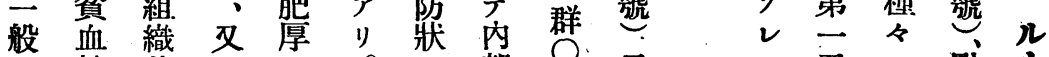

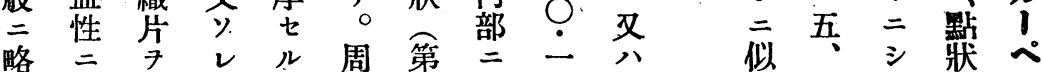
々 シ 附 7 壁壁九彎 | 楕

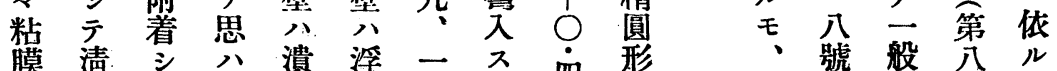
筋 满 シ ハ 潰 浮

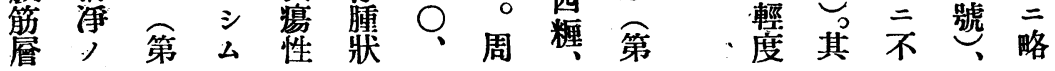




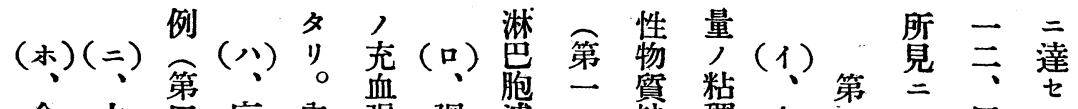

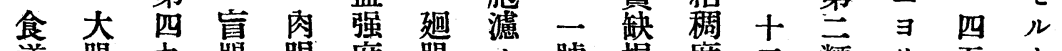

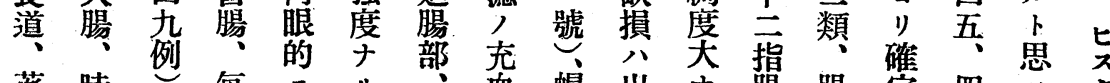

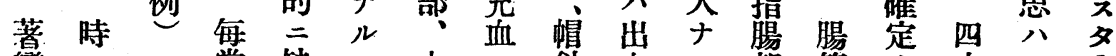

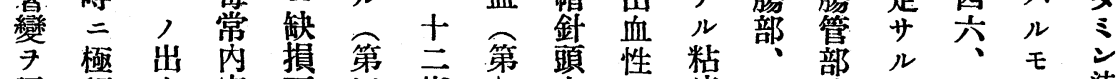

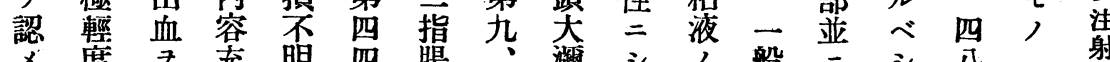

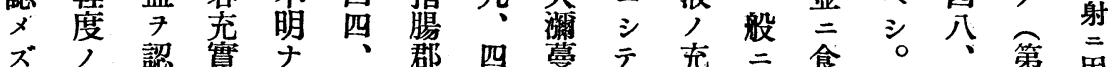
ズ 認實ナ・郡四蔓示充二食。、第茵

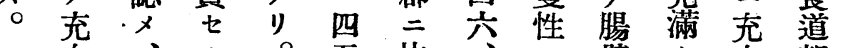
血、ル○五比、, 壁七血部 7 時 $モ$ 其、 コ二特看九充八, 橫 7 中

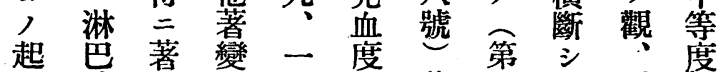

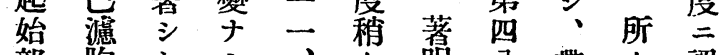

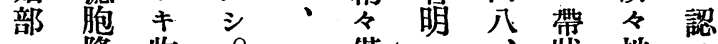

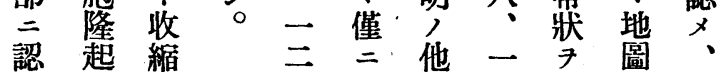

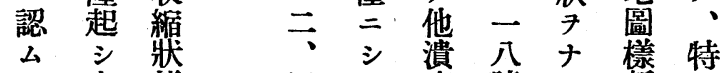
充態 他 血 7 策認 算來玆 九第待

$\rightarrow$ 四 粘

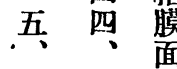

入品喗

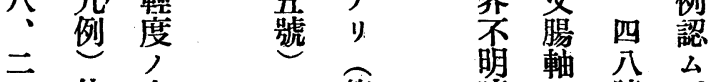

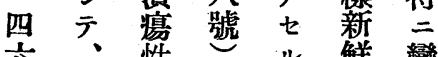

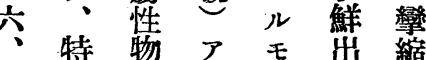

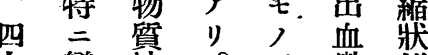

七 攀缺。微態 維損其第量 7

四七刀，一早 凡㒛周一穿昱 モx㟟二九必

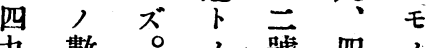

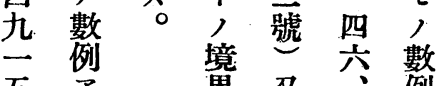

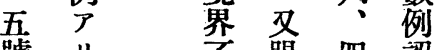

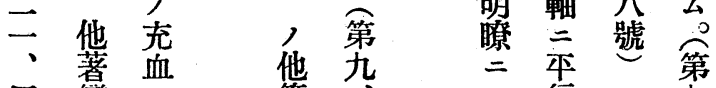

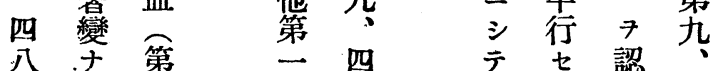

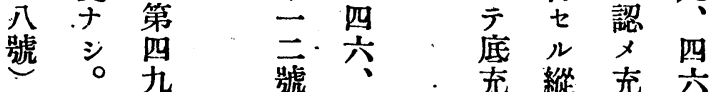
藷杂

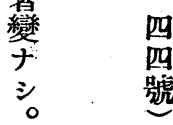

四

或

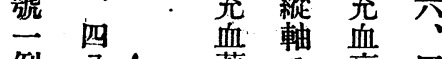

例分・蓄笋亮四

出越音有唇分

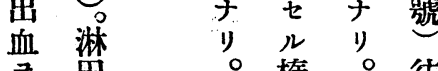

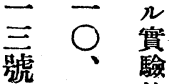

一 的

等

5 四 瓷

四成

西罗度

势 积

雨 视

者面䨂

梁

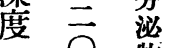

差只惣

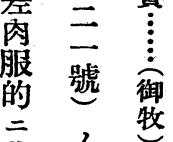

其 他

㥎 更

型

$r$ r

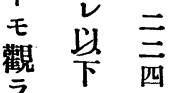

5

思

答分

专

基楕魔将

䫝第 


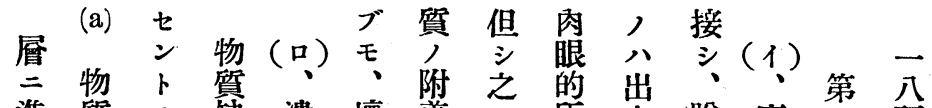

進質 ス 缺潰 壞着公所血脫糜一頭

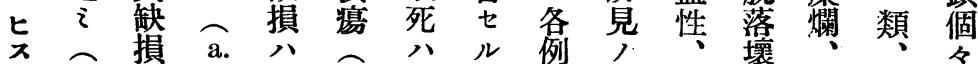

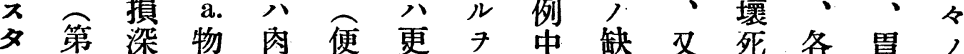

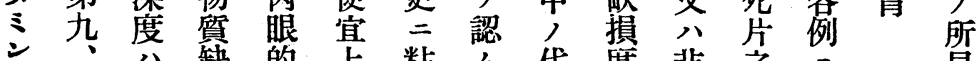

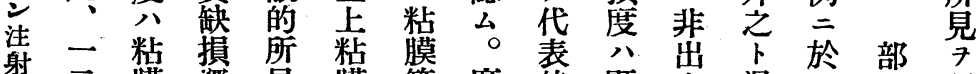

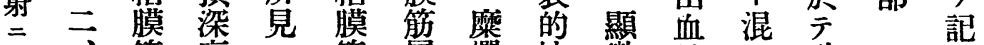

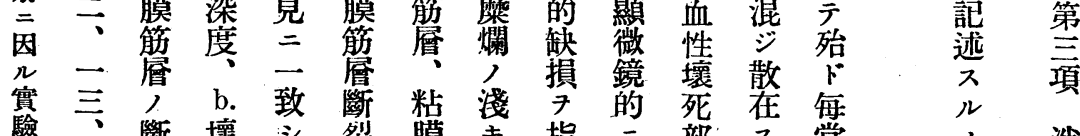

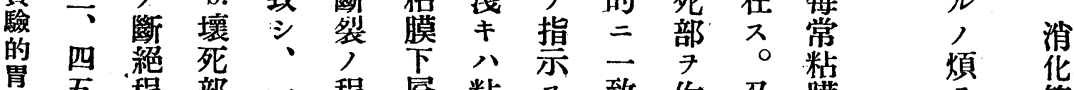

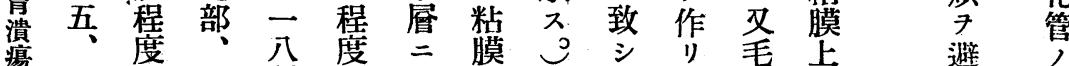

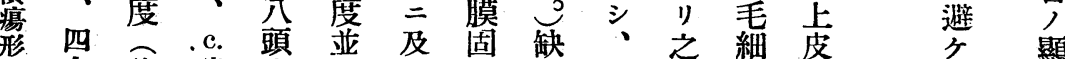

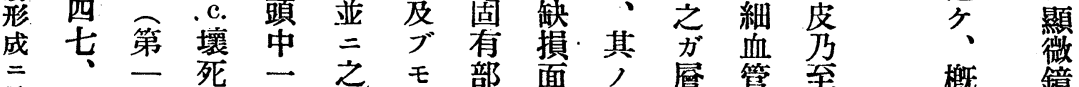

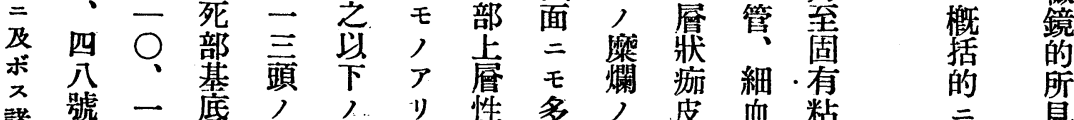

楛

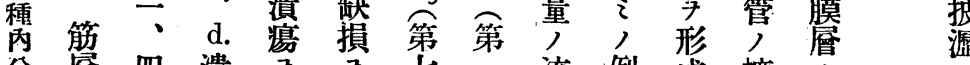

分詹四潰 7 七公流例成擴,

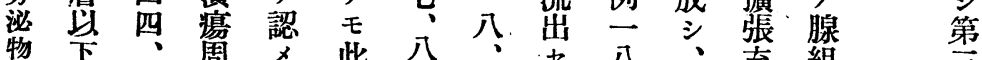

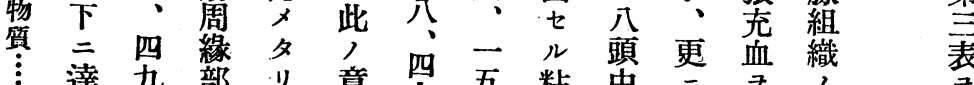

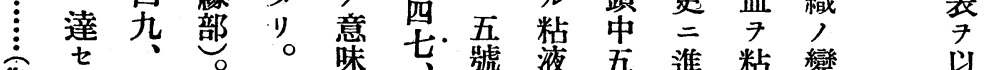

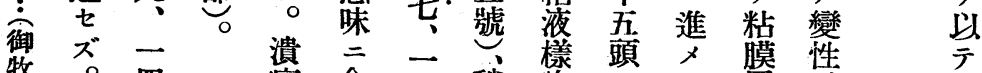

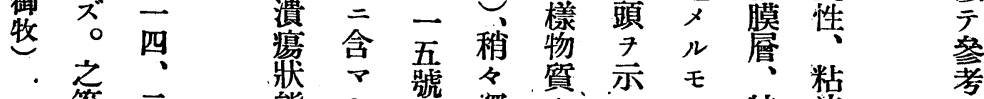

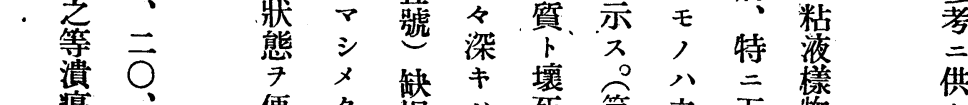

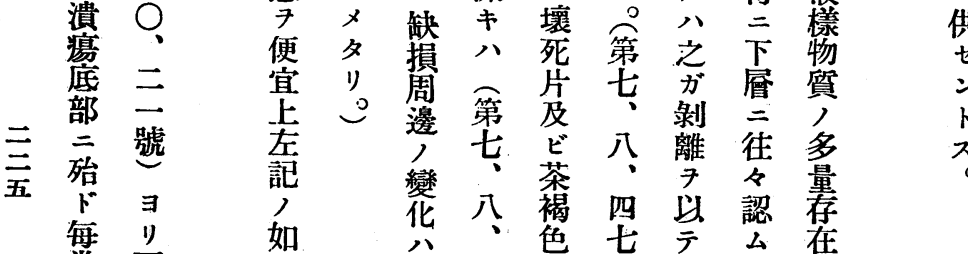

常更㠰潰四色导所台存

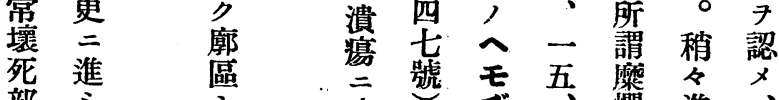

部

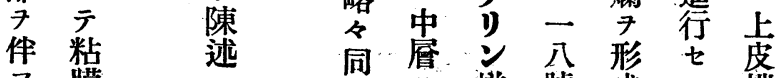

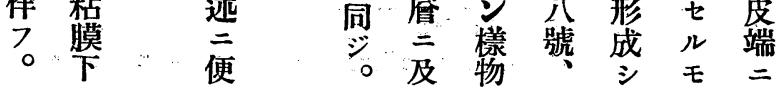


顯微鏡的所見

\begin{tabular}{|c|c|c|c|c|c|c|c|c|c|c|c|c|c|c|c|c|}
\hline 並 & $=$ 其 & 1 & 周 葟 & 1 & 顯 & 教 鏡 & 的 & 所 見 & & & & & & & & \\
\hline 粘膜 & 固有斤 & & 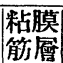 & & 粘 & 膜 & 下 & 層 & & 筋 & & 啳 & & 膜 & & 䏐損 \\
\hline 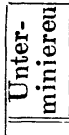 & 血 & 血 & 性 & 血 & 血 & $\begin{array}{l}\text { 浮 } \\
\text { 腫 } \\
\end{array}$ & $\begin{array}{l}\text { 細 } \\
\text { 胞 } \\
\text { 浸 } \\
\text { 潤 } \\
\end{array}$ & 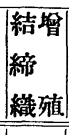 & $\begin{array}{l}\text { 血 } \\
\text { 管 } \\
\text { 新 } \\
\text { 生 } \\
\end{array}$ & $\begin{array}{l}\text { 細 } \\
\text { 胞 } \\
\text { 浸 } \\
\text { 潤 } \\
\end{array}$ & 厚 & 性 & $\begin{array}{l}\text { 細 } \\
\text { 胞 } \\
\text { 浸 } \\
\text { 潤 } \\
\end{array}$ & \begin{tabular}{|l|} 
結賭 \\
締 \\
織殖
\end{tabular} & 瘍 & 爛 \\
\hline+ & + & + & + & - & + & H & H & - & - & + & - & - & - & - & - & H. \\
\hline- & - & - & - & + & + & + & + & + & - & - & - & - & - & - & - & $H$ \\
\hline H & - & + & + & $H$ & + & H & H & + & - & Ht & + & - & + & - & \# & \\
\hline+ & $H$ & - & + & + & + & H & $t$ & + & + & - & - & + & - & - & + & \\
\hline- & + & - & - & + & - & 井 & + & H & + & - & + & - & + & - & + & \\
\hline- & - & $H$ & - & + & + & - & + & + & - & + & - & - & - & - & $H$ & \\
\hline+ & + & + & + & + & + & + & + & + & - & - & - & - & - & - & + & \\
\hline+ & - & + & + & + & + & + & + & $H$ & - & - & - & - & - & - & $H$ & \\
\hline+ & - & $H$ & + & $H$ & - & $H$ & HI & HI & + & $H$ & - & + & - & - & $H$ & \\
\hline+ & $H$ & - & - & + & \# & + & + & - & + & + & - & - & + & - & - & $H$ \\
\hline- & + & + & - & + & + & HI & + & Ht & + & HH & $H$ & $t$ & - & - & + & \\
\hline- & - & - & - & - & - & + & + & $\frac{1}{1}$ & + & + & + & + & - & + & + & \\
\hline- & - & - & - & + & + & + & + & H & - & - & - & - & - & - & $H$ & \\
\hline+ & + & + & + & - & - & - & + & - & - & HI & H & - & - & - & + & \\
\hline+ & + & - & - & $H$ & + & H & - & $H$ & + & H & - & - & - & + & - & + \\
\hline- & + & - & - & + & - & - & + & - & - & - & - & - & - & + & - & + \\
\hline- & - & - & - & - & - & H & + & + & - & + & - & - & - & - & + & \\
\hline- & + & - & - & + & + & - & $H$ & HI & - & + & - & - & - & - & + & \\
\hline
\end{tabular}


第三表 肉眼的並 =

\begin{tabular}{|c|c|c|c|c|c|c|c|c|c|}
\hline \multirow{4}{*}{$\begin{array}{l}\text { 群 } \\
\text { 別 }\end{array}$} & \multirow{4}{*}{$\begin{array}{l}\text { 海 } \\
\text { 獏 } \\
\text { 番 } \\
\text { 號 }\end{array}$} & \multirow{4}{*}{$\begin{array}{l}\text { 性 } \\
\text { 別 }\end{array}$} & \multicolumn{4}{|c|}{ 肉 眼 的 所 見 } & \multicolumn{3}{|c|}{ 缺 搷 } \\
\hline & & & \multirow{3}{*}{ 形 } & 大 直 & \multirow[t]{2}{*}{ 周 } & \multirow{3}{*}{ 底 } & \multirow[t]{3}{*}{ 缺 深 } & \multirow{3}{*}{$\begin{array}{l}\text { 噮 及 } \\
\text { 死 } \\
\text { 波 度 }\end{array}$} & \\
\hline & & & & & & & & & 㕷 \\
\hline & & & & $\begin{array}{c}\text { サ 徑 } \\
\text { (框) }\end{array}$ & 邊 & & & & \\
\hline \multirow{5}{*}{ 第 } & 7 & $\hat{\delta}$ & 圓 & 0.2 & 堤防狀 & $\begin{array}{l}\text { 涺 } \\
\text { 褐 } \\
\text { 色 }\end{array}$ & \begin{tabular}{|l} 
固有粘膜澬 \\
中 部 迄
\end{tabular} & $\begin{array}{l}\text { 粘膜下㞗 } \\
\text { 中 部、遥 }\end{array}$ & \# \\
\hline & 8 & ㅇ & 點 & 0.15 & " & "I & " & 粘膜筋㞗艺 & + \\
\hline & 9 & $\hat{\delta}$ & 圓 & 0.2 & " & 清 淨 & 粘膜下稂 & 粘膜下痸 & H \\
\hline & 10 & 0 & II & 03 & II & 污 穖 & 粘膜筋筧 & II & \pm \\
\hline & & & & & & 襍 色 & 崘 裂 迄 & 蛅腊下廉 & \\
\hline \multirow[t]{2}{*}{ 群 } & 11 & $\hat{\jmath}$ & "I & 0.2 & 噴火口狀 & "I & "I & 上部眨 & - \\
\hline & 12 & 우 & "I & ó.3 & " & 静 淨 & $\begin{array}{l}\text { 粘膜下筧 } \\
\text { 中 部 汽 }\end{array}$ & $\begin{array}{l}\text { 粘膜下瓷 } \\
\text { 底 部 迄 }\end{array}$ & - \\
\hline \multirow{3}{*}{ 第 } & 44 & $\hat{o}$ & 棈圓 & $0.4 \times 0.2$ & 堤防狀 & 污 穖 & 粘膜筋㞗 & 粘膜筋層迄 & H \\
\hline & 45 & 우 & 圓 & 0.4 & 噴火口狀 & & $\begin{array}{l}\text { 粘膜下䚄 } \\
\text { 中部法 }\end{array}$ & $\begin{array}{l}\text { 粘膜下䚄 } \\
\text { 底部 }\end{array}$ & + \\
\hline & 46 & $\hat{\delta}$ & 棈圓 & $0.3 \times 0.1$ & 堤防狀 & "I & " & 內輪筋層艺 & + \\
\hline 二 & 47 & ?ִ & 圓 & 0.1 & $" \prime$ & " & $\begin{array}{l}\text { 固有粘膜屬 } \\
\text { 中 部 }\end{array}$ & 粘膜筋層汽 & H \\
\hline \multirow[t]{2}{*}{ 群 } & 48 & $\delta$ & "I & 0.2 & 噴火口狀 & " & $\begin{array}{l}\text { 粘膜下睸 } \\
\text { 中部迄 }\end{array}$ & 内輪筋層汽 & + \\
\hline & 49 & 우 & 楕圓 & $0.5 \times 0.1$ & 堤防狀 & " & $\begin{array}{l}\text { 粘膜筋䚄 } \\
\text { 斷 裂 迄 }\end{array}$ & ij & + \\
\hline \multirow{3}{*}{ 第 } & 13 & $\delta$ & 圓 & 0.1 . & 噴火口狀 & $\begin{array}{l}\text { 污 峨 } \\
\text { 褐 色 }\end{array}$ & $\begin{array}{l}\text { 粘膜下磿 } \\
\text { 中部汽 }\end{array}$ & $\begin{array}{l}\text { 粘膜下䚄 } \\
\text { 部治 }\end{array}$ & - \\
\hline & 14 & 우 & "I & 0.3 & " & $\begin{array}{l}\text { 清 淨 } \\
\text { 存白色 }\end{array}$ & 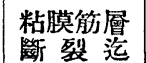 & $\begin{array}{l}\text { 粘膜下層 } \\
\text { 中部迄 }\end{array}$ & + \\
\hline & 15 &.$\hat{~}$ & 正三角 & 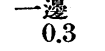 & 階段狀 & " & 固有粘膜䚄 & 粘膜筋膡汽 & + \\
\hline 三 & 18 & 우 & 圓 & 0.15 & & 污 穖 & & $\begin{array}{l}\text { 固有粘膜屬 } \\
\text { 底 部 迄 }\end{array}$ & - \\
\hline \multirow[t]{2}{*}{ 群 } & 20 & $\hat{\delta}$ & " & 0.15 & 堤防狀 & "I & $\begin{array}{l}\text { 粘膜筋首 } \\
\text { 斷裂迄 }\end{array}$ & $\begin{array}{l}\text { 粘膜下䚄 } \\
\text { 上部送 }\end{array}$ & - \\
\hline & 21. & 우 & 點 & 0.1 & 階段狀 & "I & "I & 粘膜筋㞗迄 & - \\
\hline
\end{tabular}




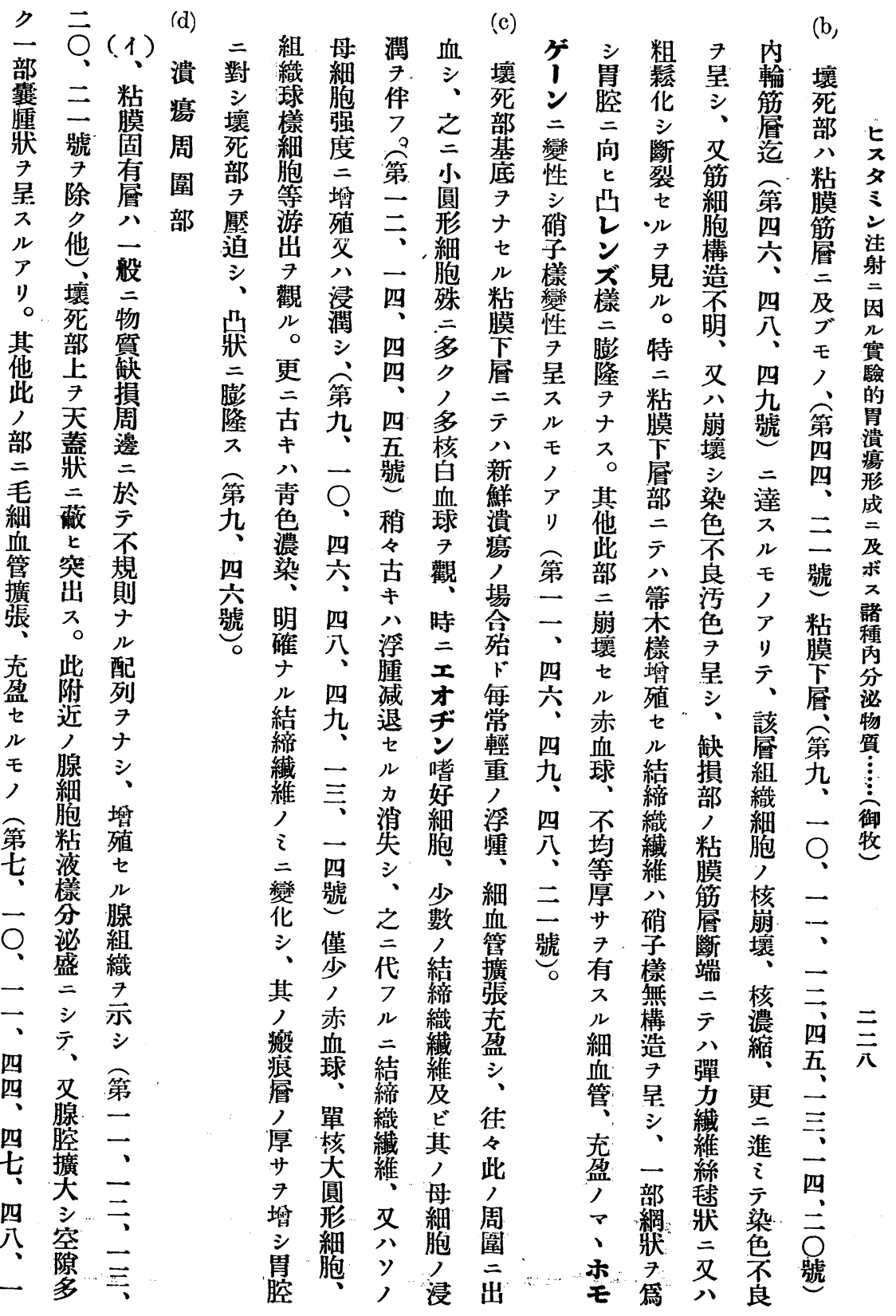




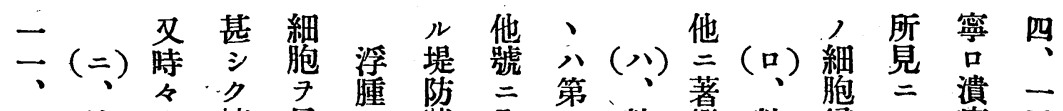

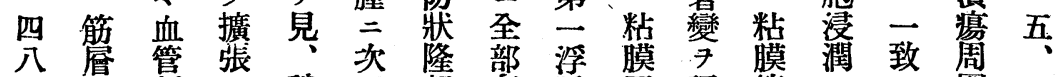

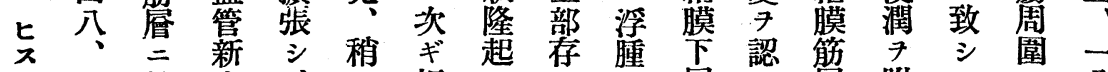

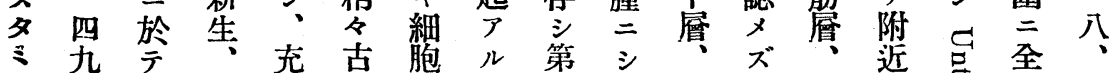

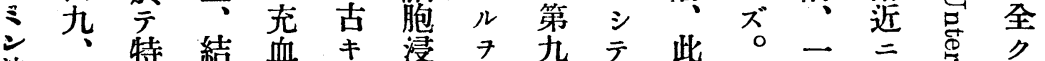

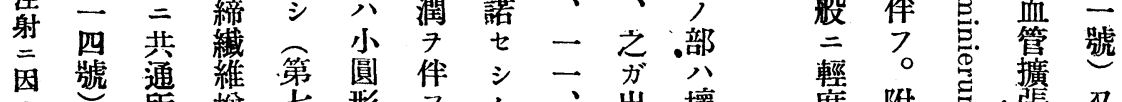

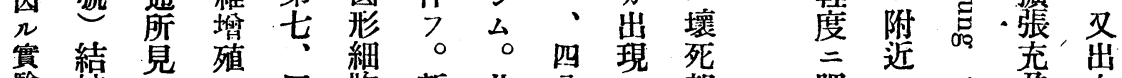
驗締子

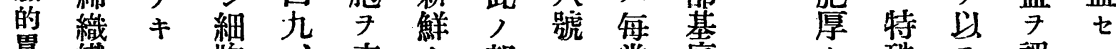

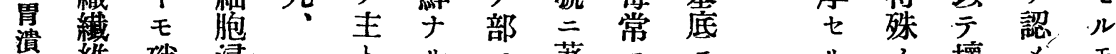

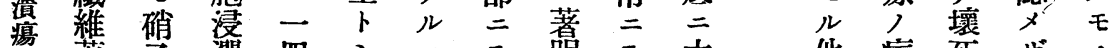

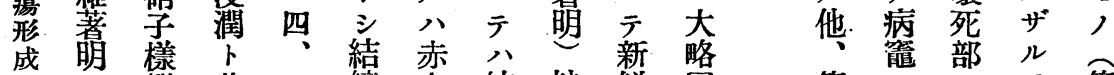

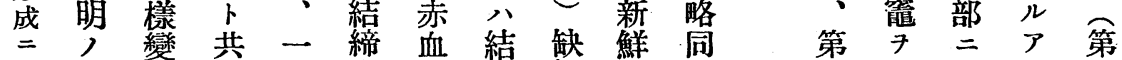

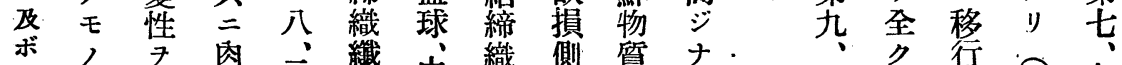

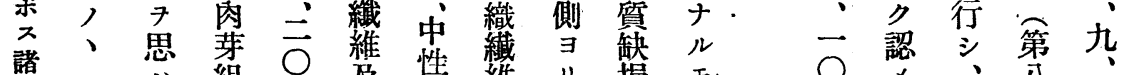

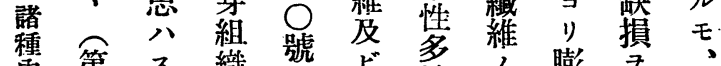
苪第 ス 織 號 ビ多, 膨子、 分四王学基核增隆有潰

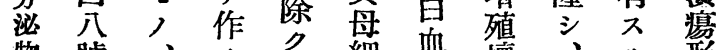

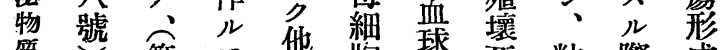

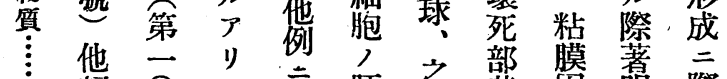

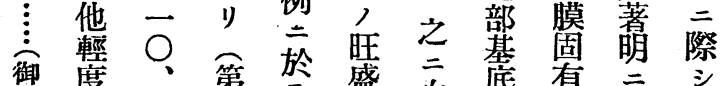

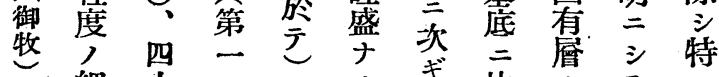
細兵、同儿式比愿吉特

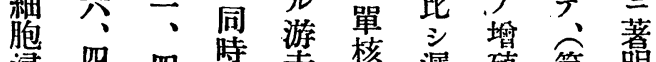
浸四四時楚逯殖第音

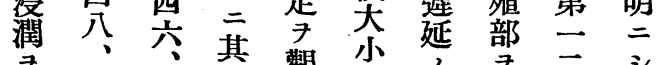

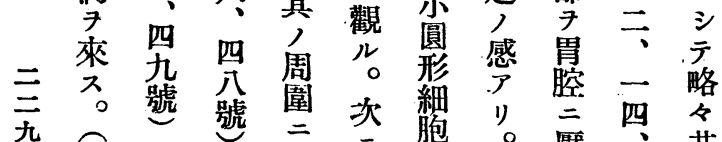

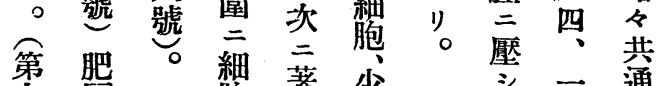

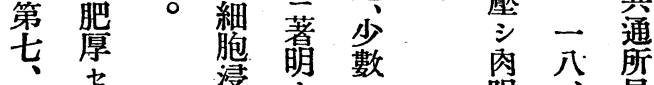

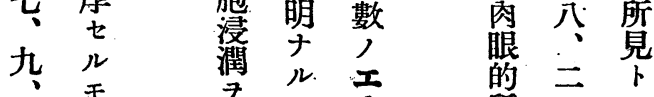
二, 往公哥留三

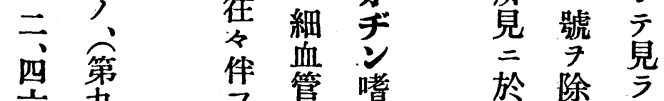
亲杂方管嘋於除吉

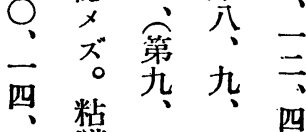

四膜 $\vec{O}$ 三四

四固 ○三人

四詹四四 五 五血四五四 四栓四四・突 窟普五亲四 於著䍗罗

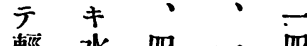
度腄四三䟊 硝見四三ア 榡 莫九號王 變一地每 性四基常 ル 號楚ナ モ輟眼 


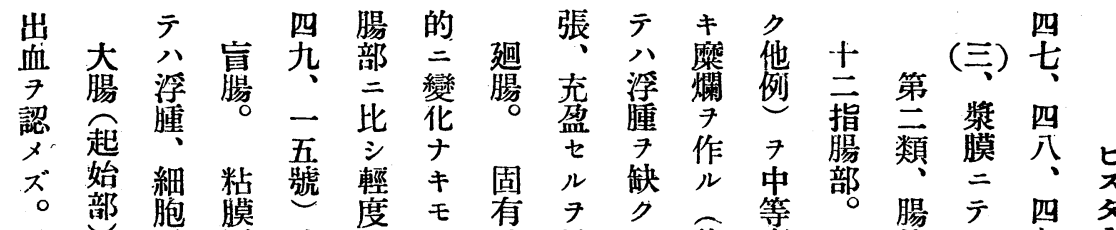

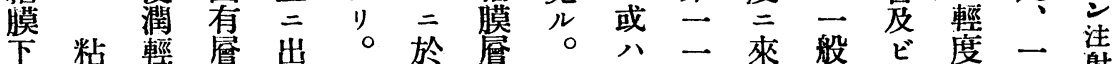

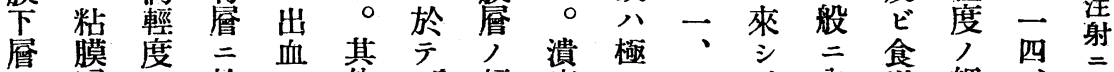

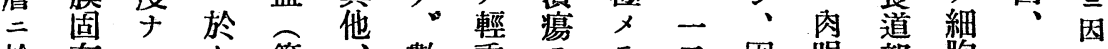

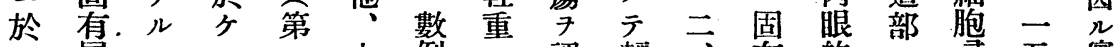

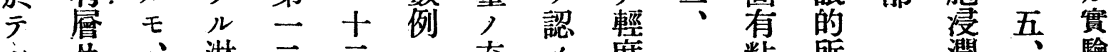

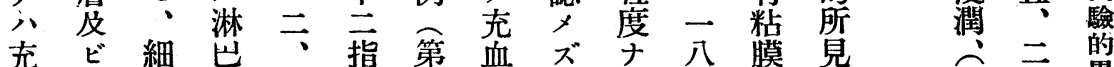

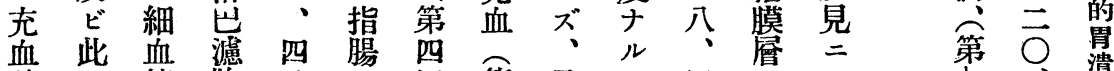
殊, 管胞公要四第乃壬四筫二 二部擴了同出出亲變致

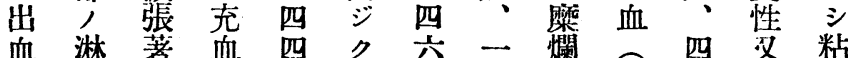

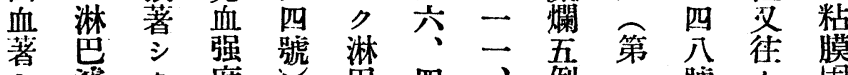

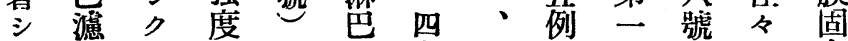

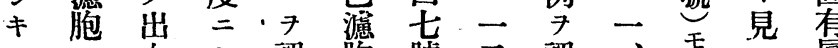

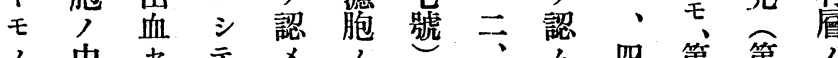
，等兄

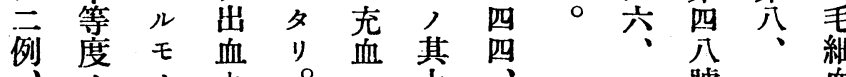

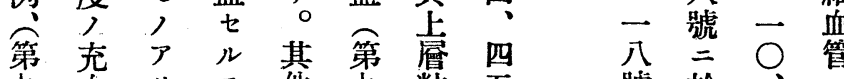
九血り七帒杂粘五、號於、

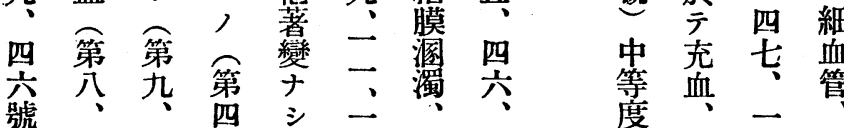
整 四 八四九四共四 水五吾號號儿二四㓡八

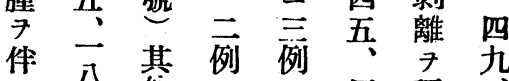
八 八焦州四認九

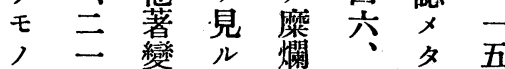

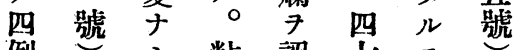

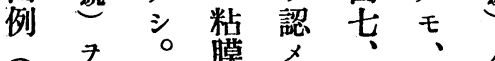

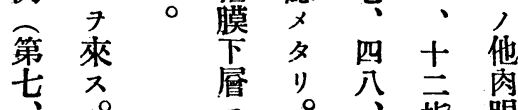

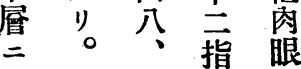

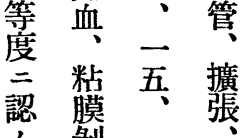

公難分克

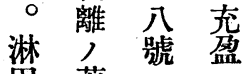

蘆著他第

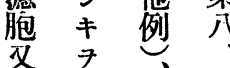
筧只簿

二三稀 四。灰

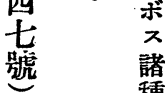
著䨌

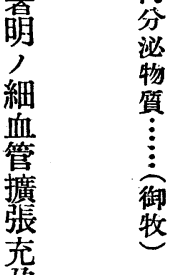
萑見亡 。部 $Q$ 袋

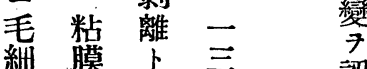

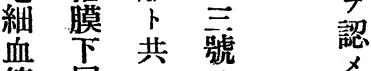

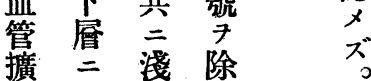


第五表

\begin{tabular}{|c|c|c|}
\hline 位 置 & 發生數 & $\%$ \\
\hline 體部 & 27 & 51.9 \\
\hline 底 部 & 10 & 19.2 \\
\hline 幽門慧部 & 5 & 9.6 \\
\hline 底，體 & 5 & .9 .6 \\
\hline 體, 幽 & 4 & 7.6 \\
\hline 幽 門 部 & 1 & 1.9 \\
\hline 合 計 & 52 & \\
\hline
\end{tabular}

胃

潰

形

成

三 稍 生 體

及实

前ル發

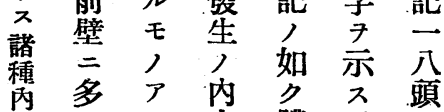

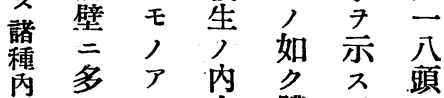

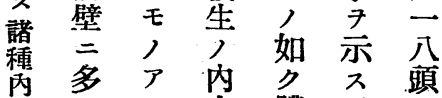

分业少

泌方 キ彎 部

物 如 $0=$

質 揱 接 次

蓹
第四表

\begin{tabular}{|c|c|c|c|c|}
\hline & 第一群 & 第二碓 & 第三群 & 總計 \\
\hline 對照例數 & 6 & 6 & 6 & 18 \\
\hline 潰瘍例數 & 4 & 5 & 4 & 13 \\
\hline$" \%$ & 66 & 83 & 66 & 72 \\
\hline 純新烟闌例數 & 2 & 1 & 2 & 5 \\
\hline$" 1 \%$ & 33 & 0.16 & 33 & 27 \\
\hline
\end{tabular}

但シ 純糜孄卜ハ潰瘍ヨ伴ハザル 麻爛ノミ發生セ几例 7 示ス
食

第 四

三公

罣学

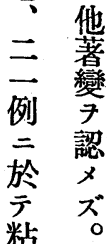

整

下

層

$=$

等

潰 尠 $\%$ 如胃 公 、示口垭海 於笔糜示公亚海第細 亏 倍闌 少頍胃云項 血 各置 二例中潰發、發潰張 發例云癔生生癔. 充 生率明三例七 䅨 ル 於ナ頭率 シ 等出 總 テ 只群 シ 頻血 胃多如 其 別、度 ₹,$=$ 八第 率 觀 注 笋 意群 不 命 潰 $\%$ 左

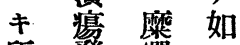
所登爛 今 》) 例 $i$ 率, 八五 第 頍 
末

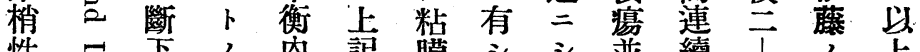

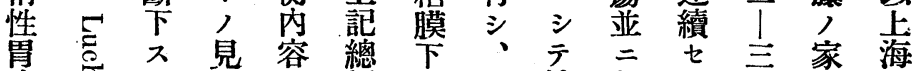

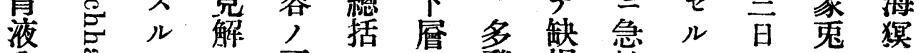

分 分 $\rightarrow$ 歪二, 發損性 $7=$

泌总現正對細性底真見於八

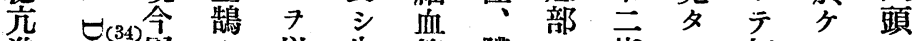

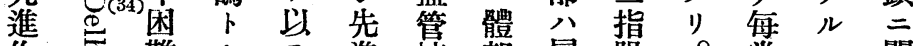

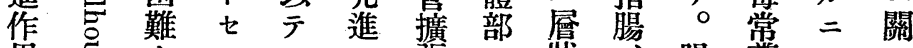

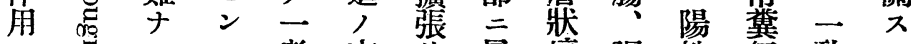

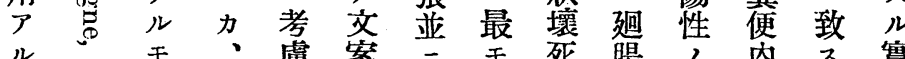

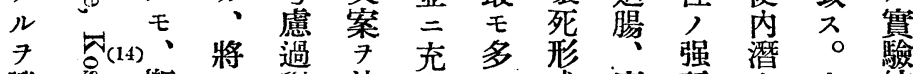

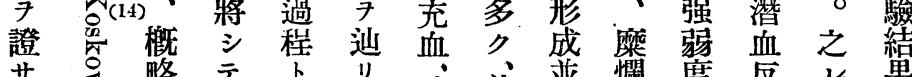

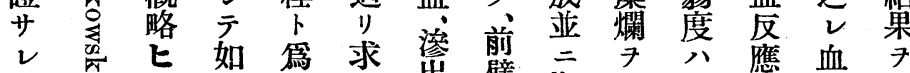

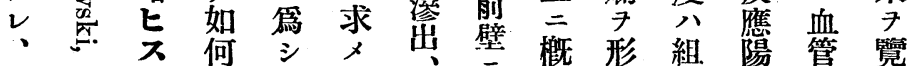
之㟔(15)多子得ン出二秒涪成織性毒

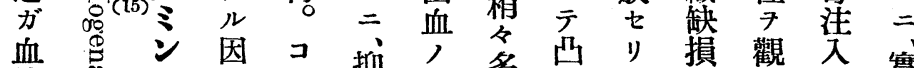

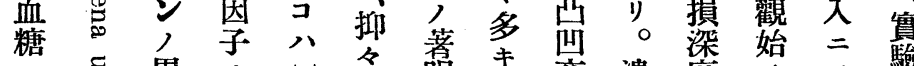

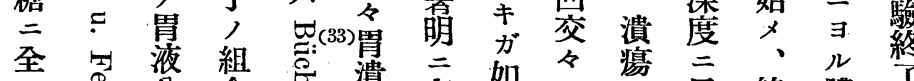

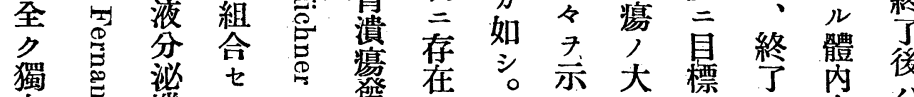

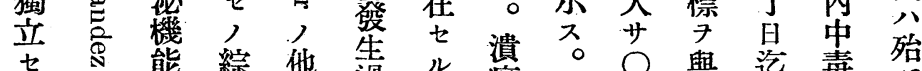

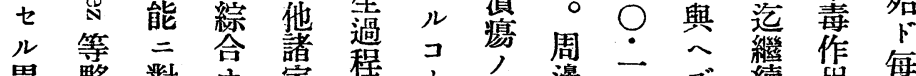
胃夥 對 ナ 蒙程卜共邊

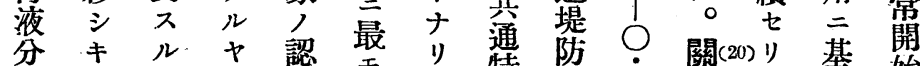

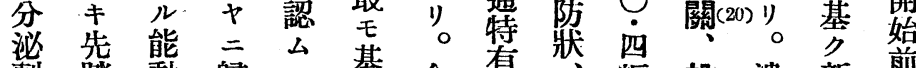

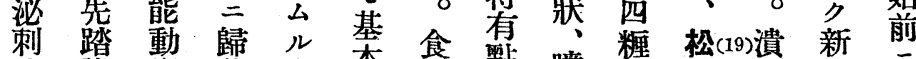

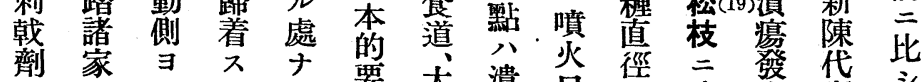

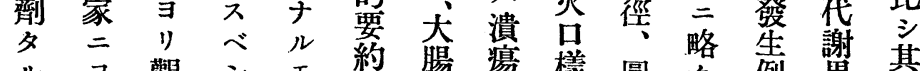

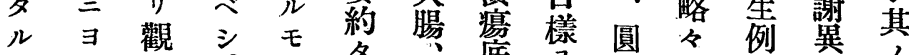
コリル・、忘底 7 時 $\rightarrow$ 常

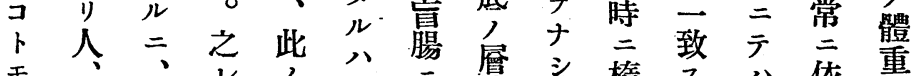

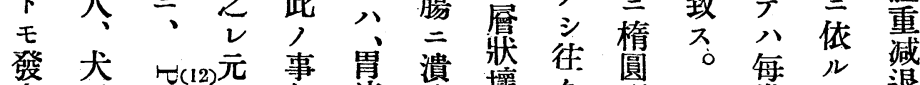

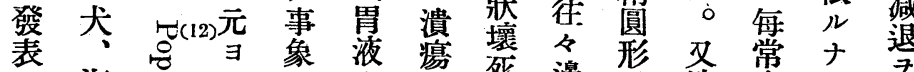
サ 海离 リ

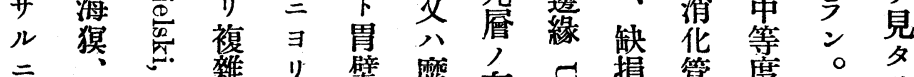

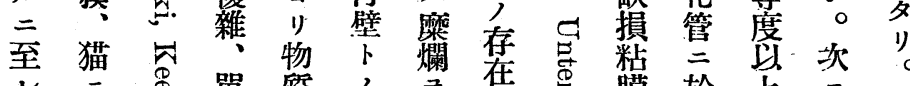

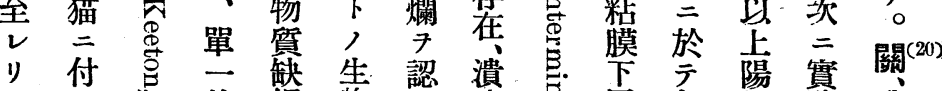
岡 ${ }^{(35)}$ 其 因(13)的圛 損 學 田共造義生的 


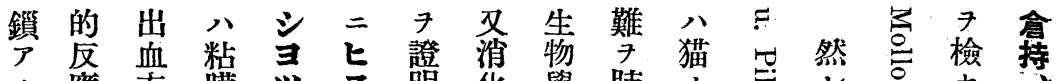
少應充 䏺

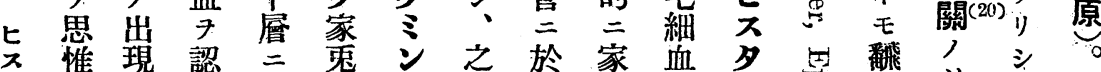

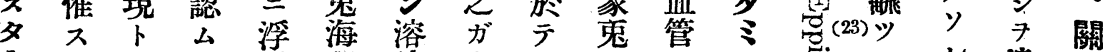

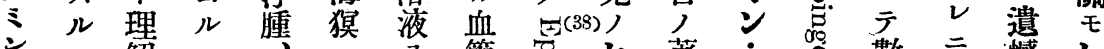

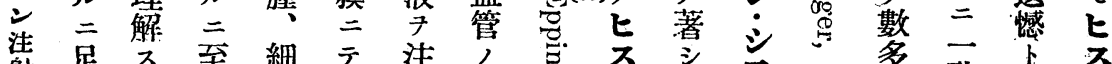

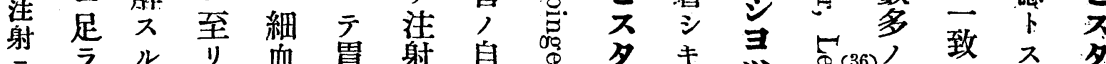

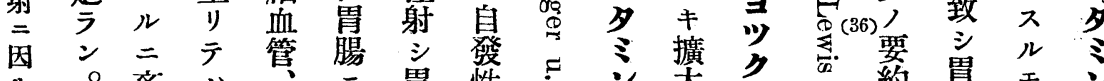

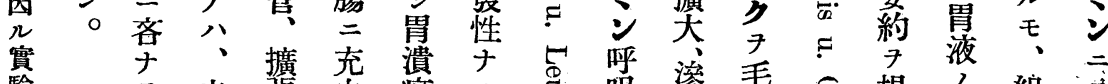
的 ズ

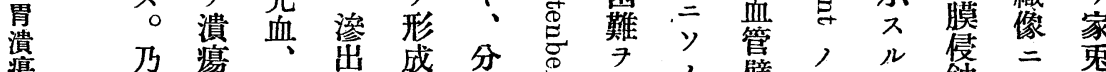
癔

形

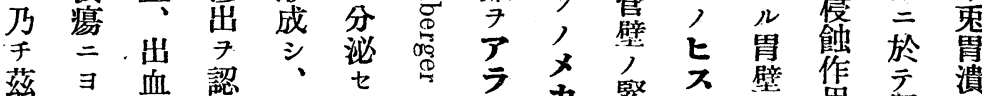

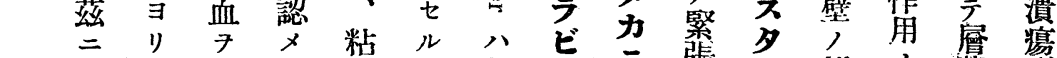

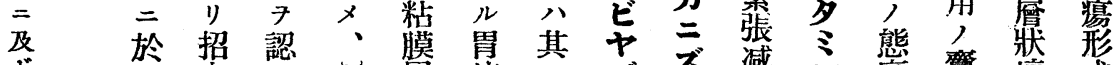

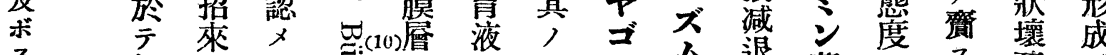
絠

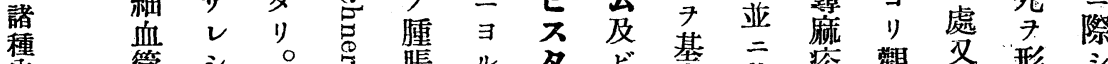

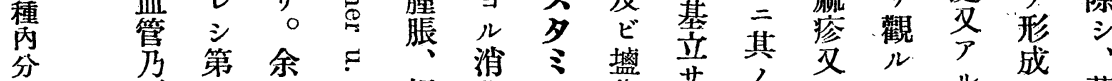

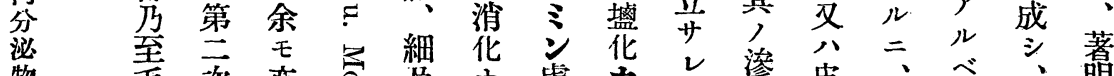

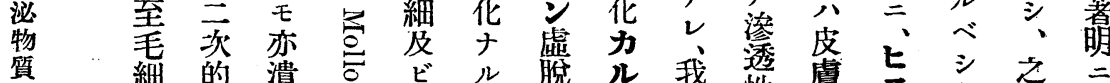

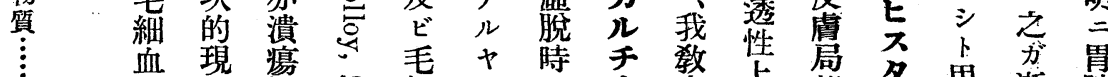

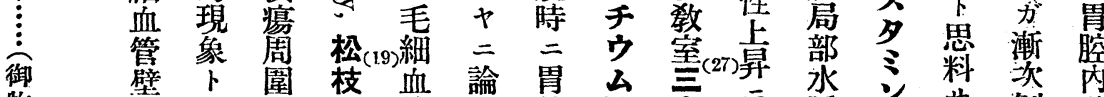

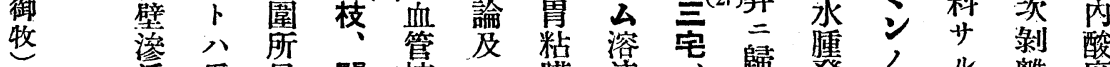

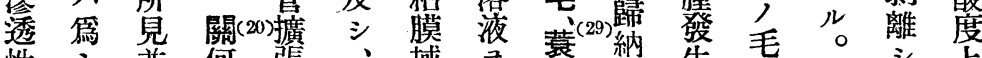

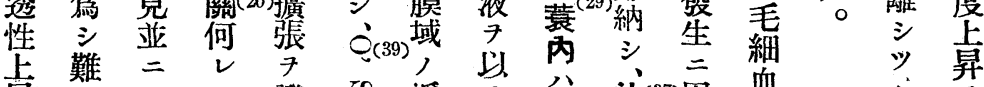
奌 人、般白明暨抑海整管證

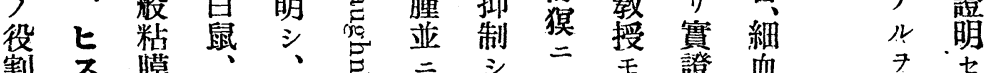

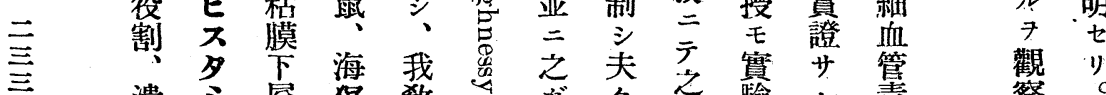

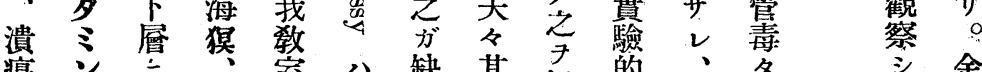

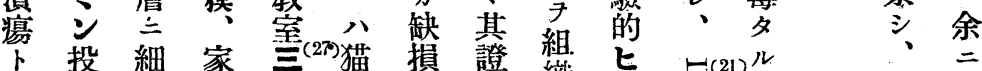

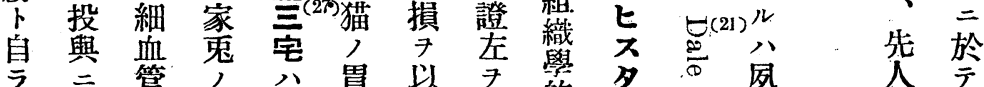

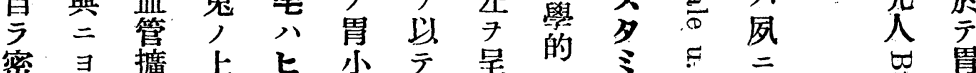

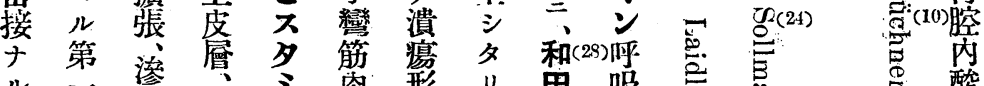
連次出又シ 内成。公困等恶 


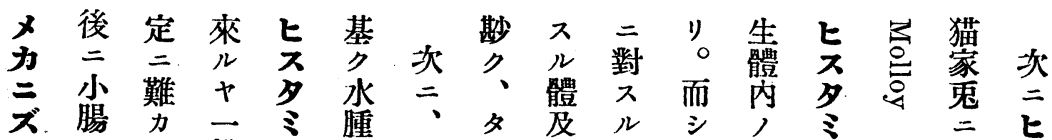

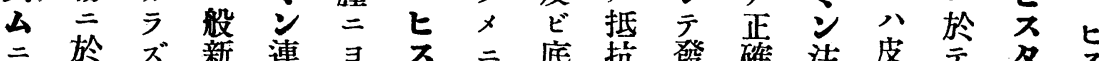
二於 $ス ゙$ 新連 $\exists ス$ 底抗發確注皮示多

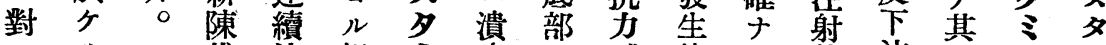

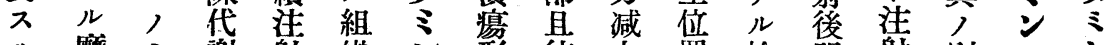

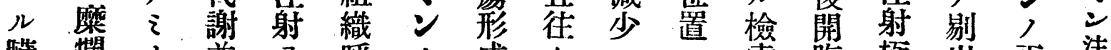

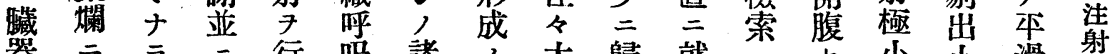
器 $三 三$ 行吸諸, 大歸就二七小滑射 ）於 ズ 內 敏 兽其分甲碍 三機

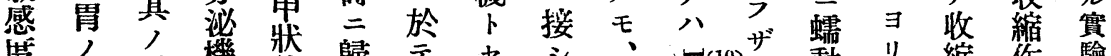
度 如役機 腺 歸 $テ$ 七

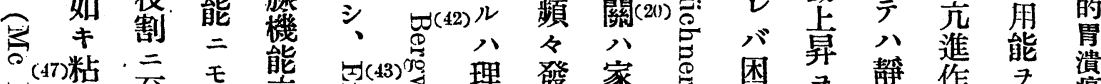

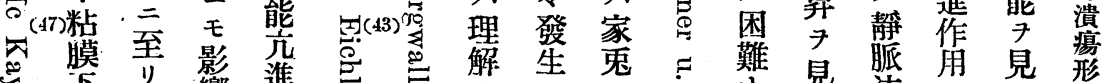

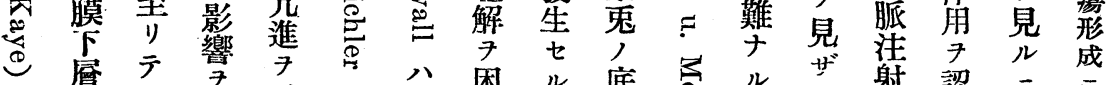

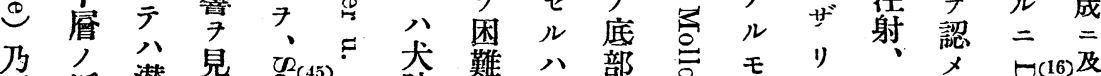

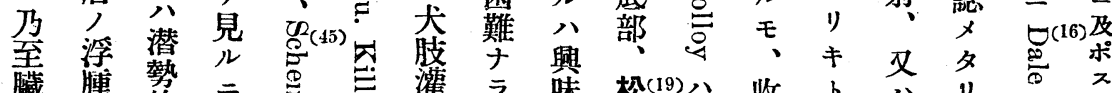

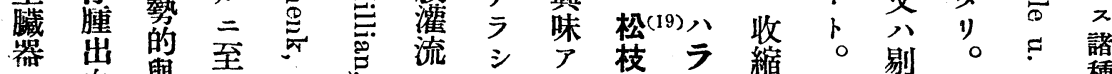

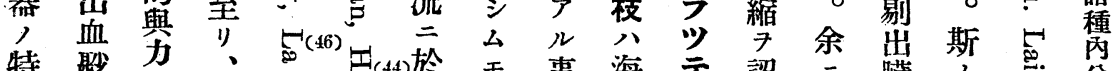

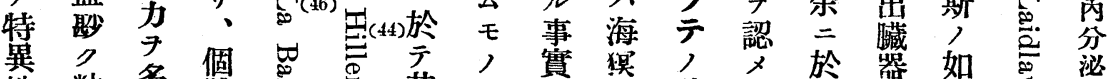

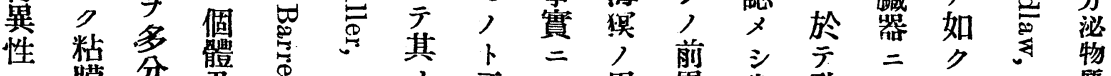

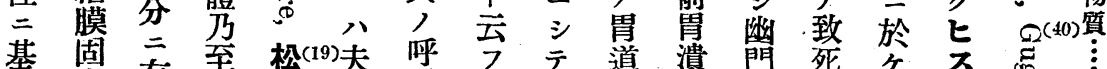

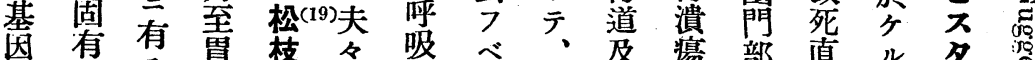

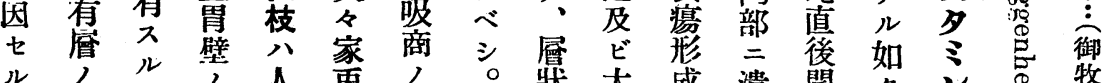

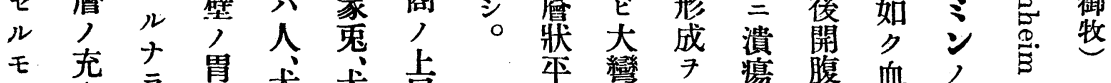

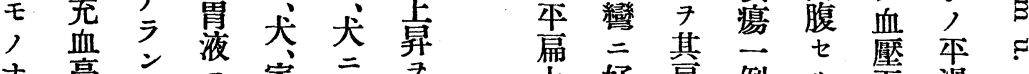

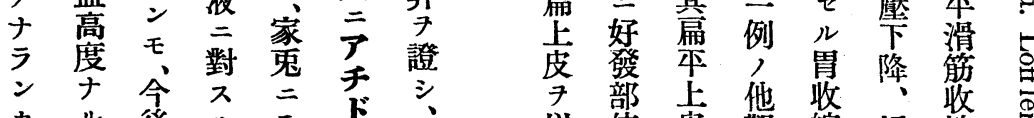

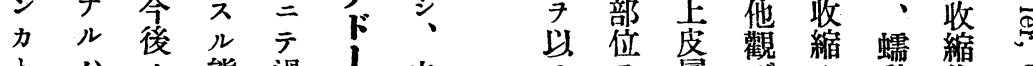

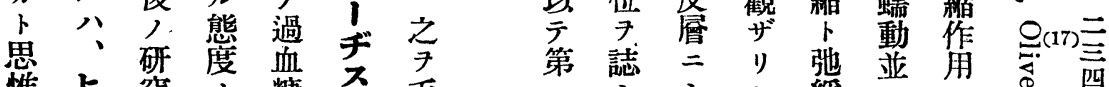

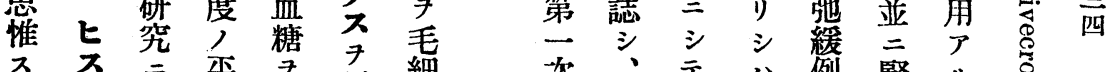

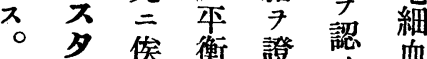

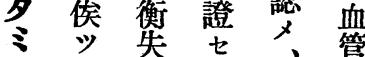
所調 リ伊(26)壁 作 $>$ 子 0 藤了 用 來 斯 八滲 ’ンス家 透 同。公觀 兔 性

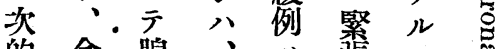
的余腺、公張二 胃王細 洼略占對〈(41)

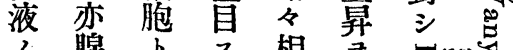

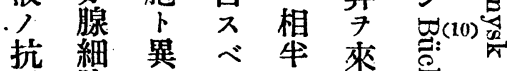

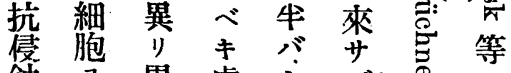
蝕 7 胃 處 方

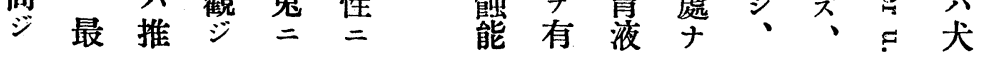


五四三部三十檢

本擱發胃潰 7 界急采余

諭筆 生潰癔成潰 性、海

ス交臨置發圍、少潰, 方

女要江生並 污一瘍結八

三旨御二例二輱個亚論頭

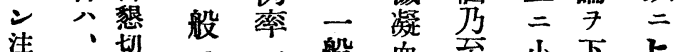

射第切 二 一般 血至小下七

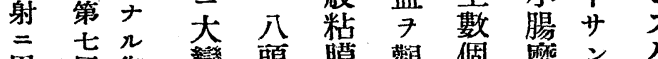

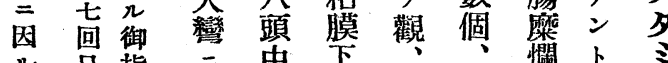

實本導 近二

驗内占”三邊草形。水

的分御體㖽殆堤直成溶

胃泌校部其

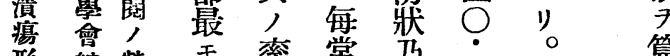

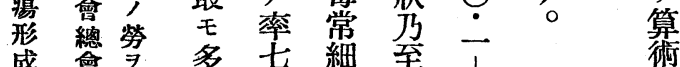

成會素賜 多 七細 至

及年界、 $\frac{0}{0}$ 管炎?

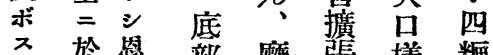

諸方恩部 魔 張 樣 糎

種登落艺爛充 シ 圆

吩表教次方血亏 充

分泌》授代, 棈

物。樑幽發渗怼圓

質楞門生出 例形

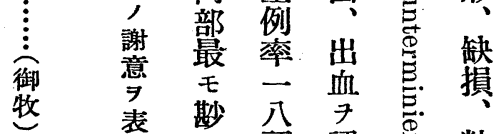
ス シ 頭認要粘

前五至

壁 頭.

二 其

秒, 迄

三 多 $\begin{array}{lll}\text { 多 } & \text { 卒 } \\ \text { 五 } & \text { 橽 }\end{array}$

F

連

綘

$\underset{⿴ 囗 十 ⺝}{E}$

間

华

注

射

消

华
多

如 $\underset{7}{\text { 示 }}$

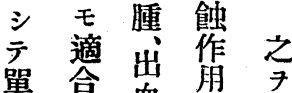

單 血 二 要

的儿所就

要 條 見テ ル

$=$ 子小心二

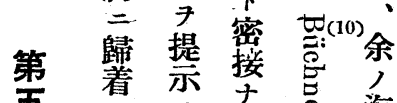

五息示觉海

章難 今關た崦

結常廣集各不

當義推导多

唯 血管 得 如 胃

茲军 今゙ 如潰

論 海 興 吕放 湯

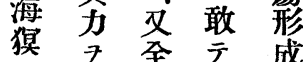

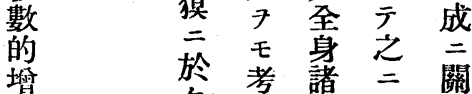

量 々 慮 種第 ス

上. ヒ ル 陳 義 限

管

=

底

多

ク

瓷、織

學

的
不倲䓯限

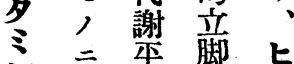

畋 シ 衡 黠 ス

潰テ、調 置

成壁寻韭胃

事胃胃 ズ 夜

象液 液 シ 分

亚卜二

組 京對 一 雚

織本 衡面伤

學垁胃上角

的調壁 記 二

性ナ了血

浗概 停 擴 胃

述念蝕 笑

此複角盛壁
瘍胃等直 シ 
잋 $\overrightarrow{0}$

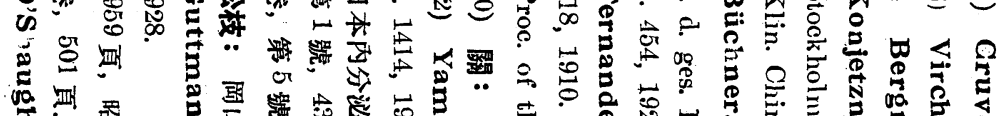

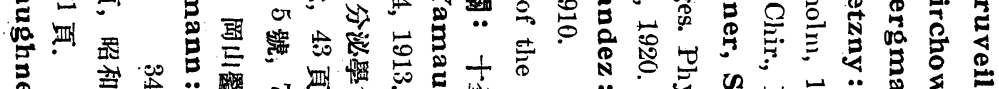

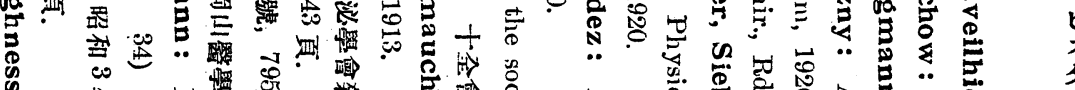
总

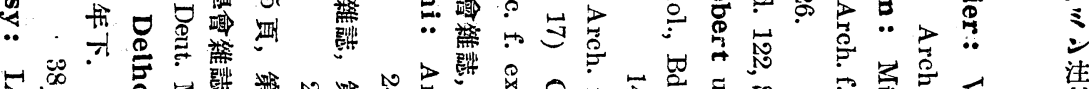

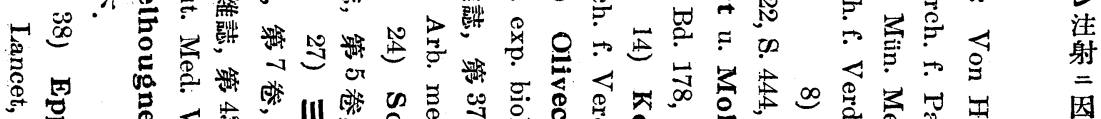

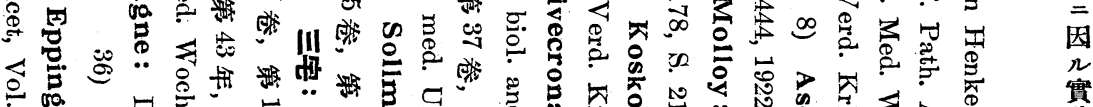
留

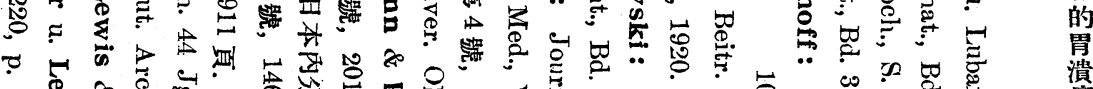

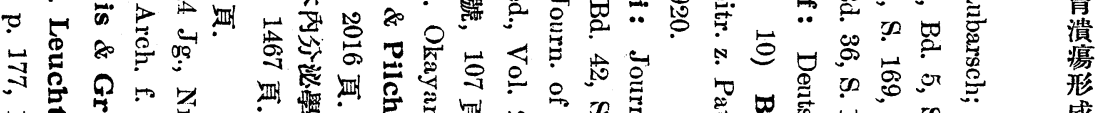

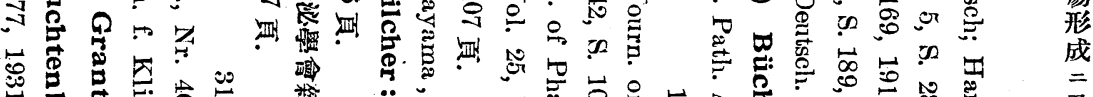

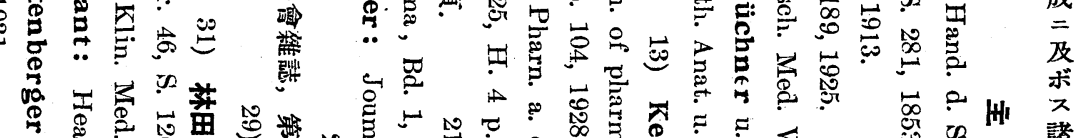

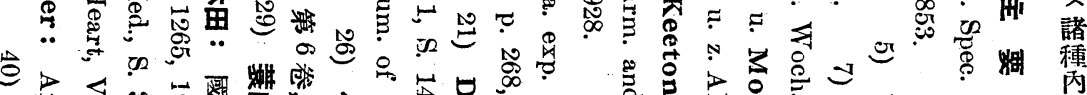

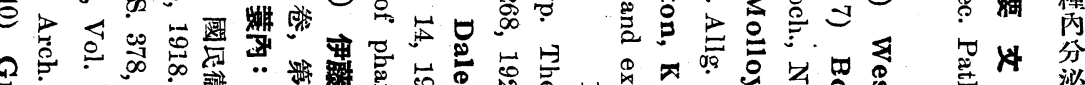

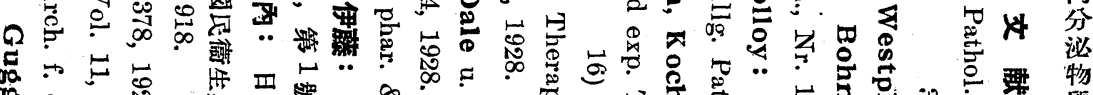

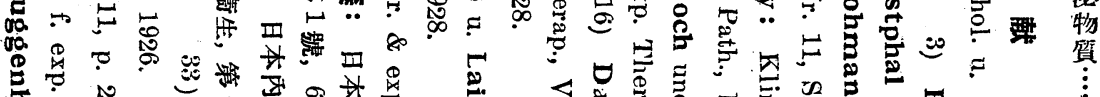

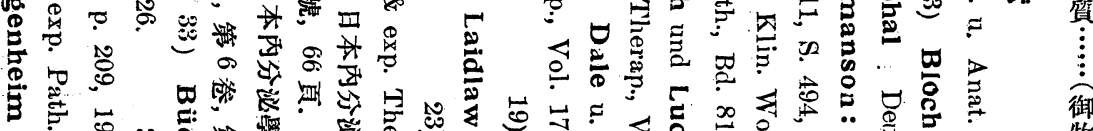
₹ F

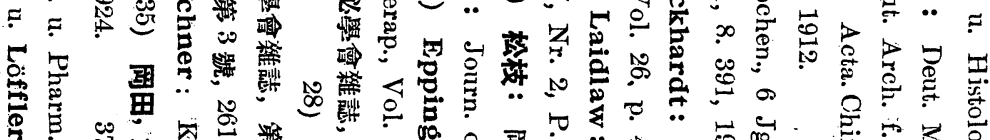

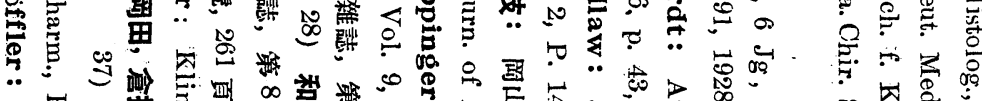

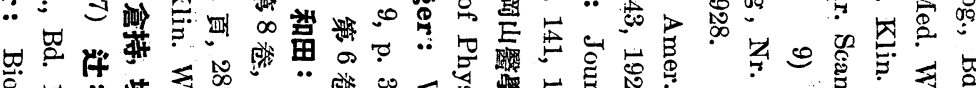

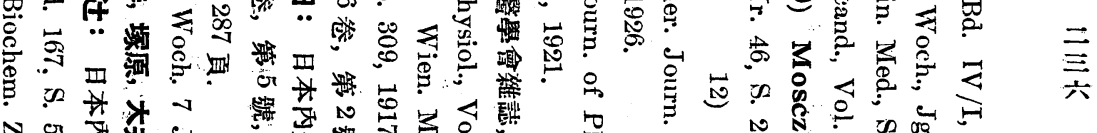

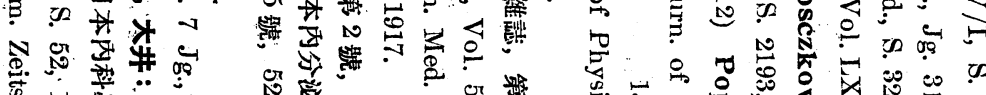

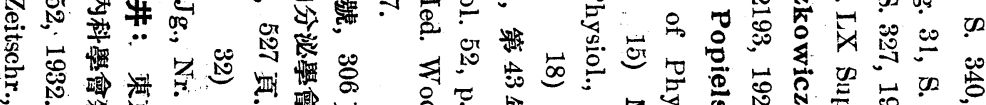

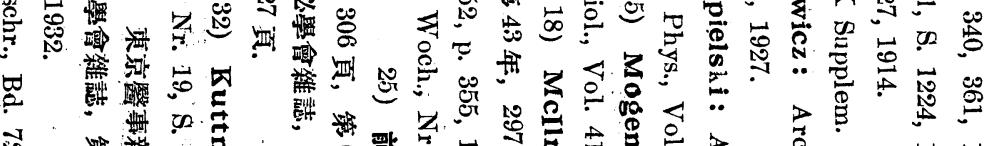
त़ 


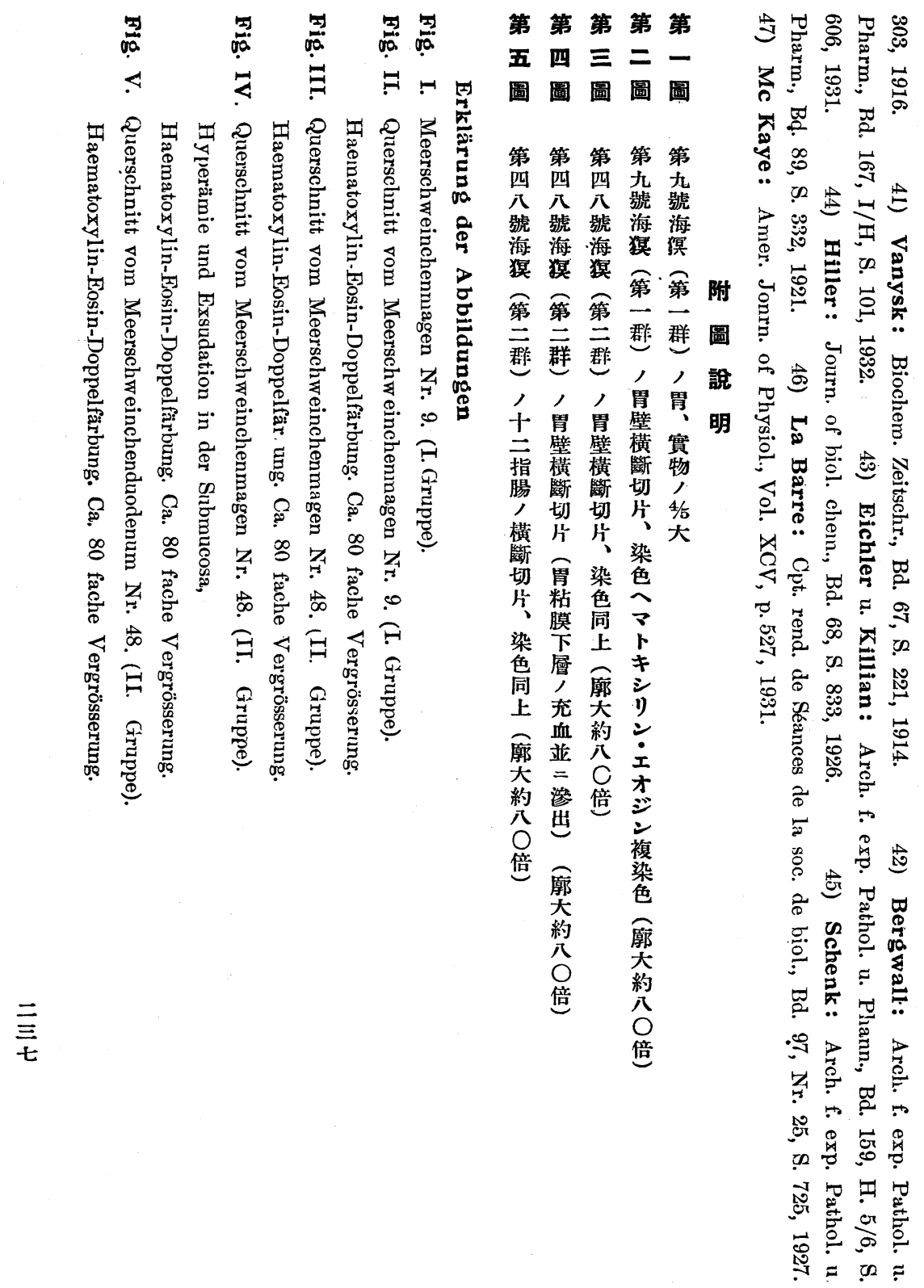


御牧諭文附圖

Fig. I.

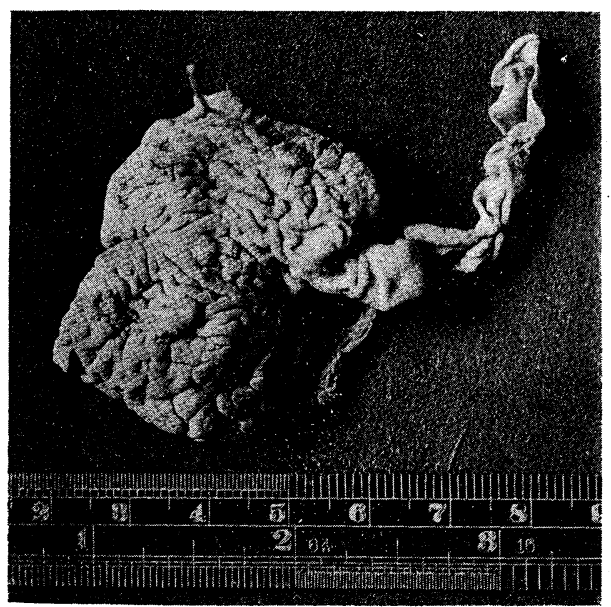

Fig. II.

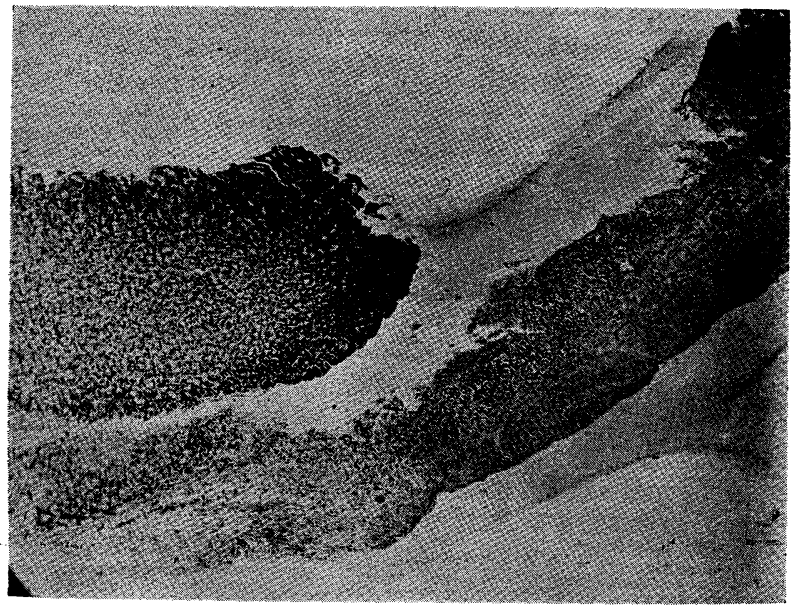


Fig. III.

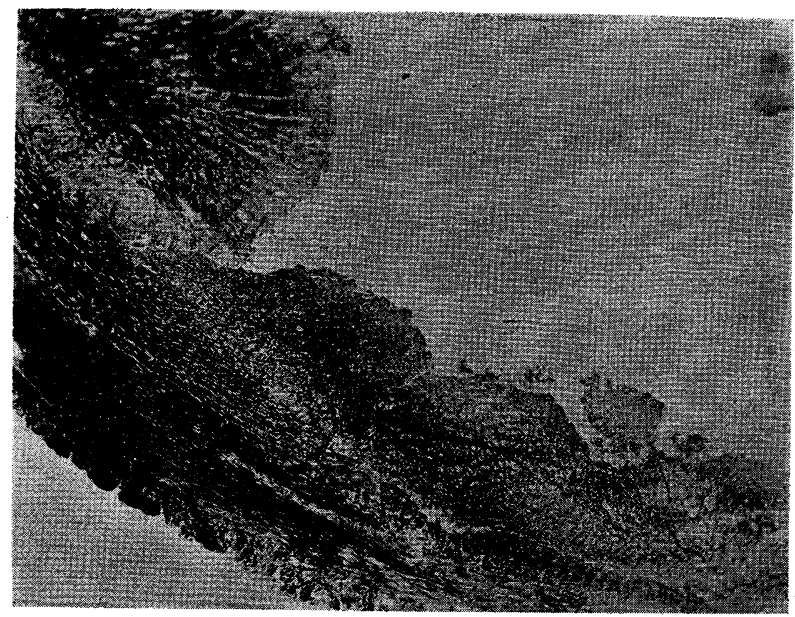

Fig. IV.

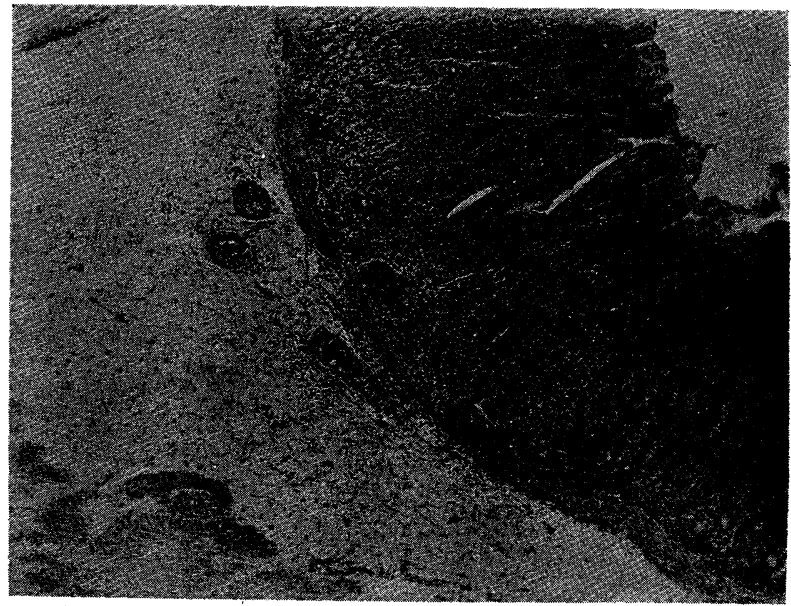

Fig. V.

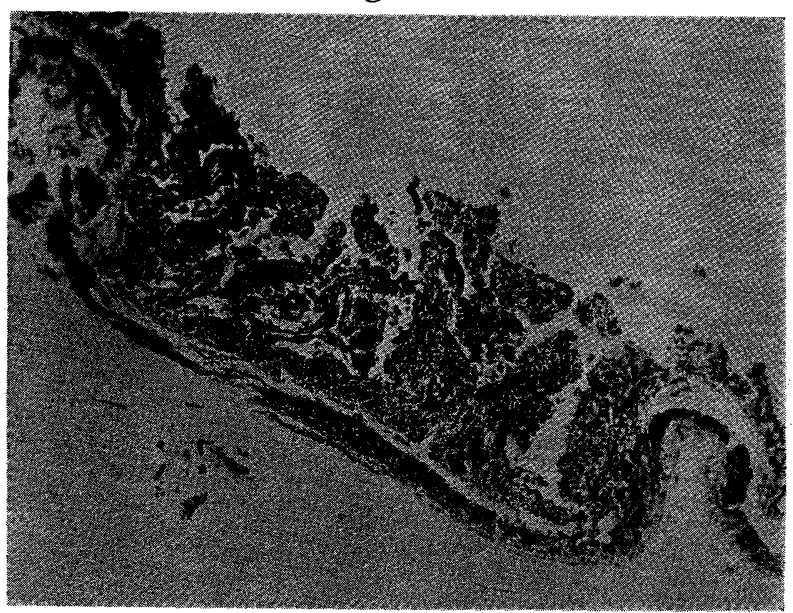




\title{
Über den Einfluss endokriner Substanzen und anderer Arzneimittel auf die Entstehung des experimentell durch Histamininjektion erzeugten Magengeschwürs.
}

\section{Mitt. Über die experimentelle Erzeugung des Magengeschwürs durch Histamininjektion.}

\author{
Von
}

Dr. S. Mimaki.

(Au» der I. Med. Klinik der Kaiserl. Universität zu Kyoto in Japan. Direktor : Prof. Dr. K. Tsuji.)

Um festzustellen, welchen Einfluss endokrine Substanzen und andere Arzneimittel auf die Entstehung des Magengeschwürs durch Histamininjektion ausüben, versuchte der Verfasser zunächst die Erzeugung des Geschwürs im Meerschweinchenmagen. Zu diesem Zwecke wurde den Tieren 7 Tage lang täglich $0.25-0.55 \mathrm{mg} 0.1 \%$ ige Histaminlösung pro $100 \mathrm{~g} \mathrm{~K}$. G. subkutan injiziert.

Die Resultate waren die folgenden:

1). Es gelang dem Verf. beim Meerschweinchen Magengeschwüre und Dünndarmerosion zu erzeugen.

2). Es entstanden ein oder mehrere Geschwüre von $0.1-0.4 \mathrm{~cm}$ im Durchmesser, die rundlich oder elliptisch, scharfrandig, wallartig, zuweilen kratarförmig, häufig schichtweise mit nekrotischer Masse und schmutzigen Blutkoagula bedeckt waren und bis auf den Grund der Submucosa reichten.

3). In der Umgebung des Geschwürs und der Submucosa wurden fast regelmässig Dilatation und Hyperämie der kleinen Gefïsse, Exsudation und Blutung angetroffen.

4). Bei $72 \%$ der Fälle kam es zum Magengeschwüre und bei $27 \%$ nur zu Magenerosionen.

5). Das Geschwür resp. die Geschwüre fanden sich im allgemeinen in der Nähe der grossen Kurratur, und zwar am häufigsten 
am Korpusteil, nächsthäufig am Fundusteil und am wenigsten häufig am Pylorusteil. Sie bevorzugten etwas häufiger die Vorder- als die Hinterwand.

(Autoreferat)

\section{Über den Einfluss endokriner Substanzen und anderer Arzneimittel auf die Entstehung des experimentell durch Histamininjektion erzeugten Magengeschwürs. II. Mitt. Über den Einfluss von Adrenalin und Schilddrüse.}

Von

Dr. S. Mimaki.

(Aus der I. Med. Klinik der Kaiserl. Univers. zu Kyoto in Japan. Direktor: Prof. Dr. K. Tsuji.)

Um festzustellen, welchen Einfluss Adrenalin und Schilddrüse auf die Entwicklung des Histamingeschwüres ausüben, injizierte der Verfasser einer Gruppe von Meerschweinchen Adrenalin subkutan wie folgt:

Am ersten Tage erhielten die Tiere 2 Histamininjektionen und 20 bie 30 Minuten vor jeder derselben eine Injektion von $0.07 \mathrm{mg}$ pro $100 \mathrm{~g} \mathrm{~K}$. G., also eine Tagesdosis von $0,14 \mathrm{mg}$. An weiteren 6 Tagen geschah dasselbe, nur mit dem Unterschiede, dass jeden Tag die auf zwei Injektionen verteilte Tagesdosis um $0.02 \mathrm{mg}$ gesteigert wurde.

Eine andere Gruppe von Meerschweinchen wurde in Untergruppen geteilt, von denen vor der Histamininjektion die erste 4, die "weite 7 und die dritte 10 Tage lang mit Schliddrüsenpulver $(0.014 \mathrm{~g}$ pro Kilo K. G.) gefüttert wurde.

Bei der dritten Gruppe exstirpierte der Verf. vor der Histamininjektion auf einer oder auf beiden Seiten die Schilddrüse. 